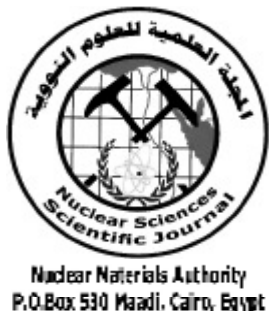

ISSN 2314-5609

Nuclear Sciences Scientific Journal

$8,17-38$

2019

http://www.ssnma.com

\title{
GEOLOGY, GEOCHEMISTRY AND RADIOACTIVITY OF GABAL SHENDIB ALKALINE RING COMPLEX, SOUTH EASTERN DESERT, EGYPT
}

\author{
HASSAN A. A. SHAHIN and MASOUD S. MASOUD \\ Nuclear Materials Authority, P. O. Box 530, El-Maadi, Cairo, Egypt
}

\begin{abstract}
Gabal Shendib alkaline ring complex forms high positive topographic rock units of concentric circular outcrop. The igneous complex has a diameter of $12 \mathrm{~km}$ emplaced within the metavolcanics and tonalitegranodiorite host rocks. The complex consists of olivine gabbro, alkaline granite, alkaline syenite and remnants of the volcanic rocks represented by porphyritic trachyte, porphyritic rhyolite, rhyolite and tuffs. These alkaline rocks show a strong enrichment in some rare metal contents $(\mathrm{Zr}=4527, \mathrm{Nb}=717$, $\mathrm{Y}=806 \mathrm{ppm})$ and rare earth elements $(\mathrm{La}=553, \mathrm{Ce}=1581, \mathrm{Pr}=214, \mathrm{Nd}=1145, \mathrm{Sm}=299, \mathrm{Gd}=55, \mathrm{Dy}$ $=85 \mathrm{ppm})$. The highest $\mathrm{Rb} / \mathrm{Sr}$ ratio and lower $\mathrm{Ba} / \mathrm{Rb}$ ratio of the studied alkaline rocks of Gabal Shendib ring complex indicating a high degree of fractionation of the melt associated with mineralization.

REE abundance patterns of the alkaline granite and alkaline syenite display M-type and W-type tetrad effect with strong Eu depletion in both whole rock samples. Fluid-melt interaction in the late stage of fractional crystallization is suggested to be the most important factor controlling the formation of REE tetrad effects in these alkaline rocks. The most important REE-bearing minerals are zircon, xenotime, monazite, allanite and apatite. Other accessory minerals include columbite, uranophane, urnothorite and titanite are identified.

Field radiometric measurements and chemical analysis for uranium content of the alkaline granite and alkaline syenite revealed low uranium content. Radioactivity level reaches up to $13.70 \mathrm{ppm}$ eU in alkaline granite and $4.90 \mathrm{ppm} \mathrm{eU}$ in the alkaline syenite. Chemical analysis of uranium revealed that $\mathrm{U}$ content reaches up to $35 \mathrm{ppm}$ in the alkaline granite and $15 \mathrm{ppm}$ in the alkaline syenite.
\end{abstract}

\section{INTRODUCTION}

Several famous and known alkaline ring complexes in the Egyptian Deserts of the PanAfrican orogenic belt, mostly circular alkaline complexes were emplaced in an intracontinental setting within the Arabian-Nubian Shield, which had been consolidated during the PanAfrican orogeny (e.g., El-Ramly and Hussein, 1985; Harris, 1985; Vail, 1985a). Emplacement of the post-orogenic or inorogenic complexes in NE Africa took place during an extended period of time spanning almost the entire Paleozoic and Mesozoic Eras (Vail, 1990).
Many authors studied the structural setting of the Egyptian alkaline complexes (e.g. Bailey, 1964; Barberi et al. 1974; Black et al. 1985). The occurrence, tectonic environments and geochronology of the Egyptian alkaline ring complexes have been reviewed by several authors (e.g., El-Ramly et al., 1969,1970 and 1971; Hashad et al., 1979; DeGruyter and Vogel, 1981; Serencsits et al., 1981; E1-Ramly and Hussein, 1985). Several authors studied the peralkaline rocks in the Eastern Desert of Egypt, e.g. El-Reedy (1979) who studied the inorganic alkaline rocks in the south East- 
ern Desert chronologically and proposed three phases of igneous activity, according to the $\mathrm{Rb} / \mathrm{Sr}$ and $\mathrm{K} / \mathrm{Ar}$ dates, they are 250-200 Ma, 155-125 Ma, and 110-70 Ma.

El Ramly and Hussein (1985) classified the ring complexes in the Eastern Desert on the basis of their magmatic differentiation, vaiety of rocks they include and on the degree of development of the ring nature into five groups namely, I) Abu Khruq type, II) Gezira type, III) Mishbeh type, IV) Mansouri type and V) Tarbite type. According to this classification, Gabal Shendib ring complex belongs to the Abu Khruq type.

Abdallah (2006) studied the REE mineralized alkaline granites in Egypt. He divided the REE-mineralized alkaline granites in Egypt into three classes: (1) Mesozoic, anorogenic nepheline syenite ring complexes with REE amounting up to $1.3 \%$, (2) anorogenic peralkaline syenite-granite, composed of i) $\mathrm{Zr}$, $\mathrm{Nb}, \mathrm{REE}$, and Th-enriched peralkaline granite-syenite complexes with REE amounting up to $0.5 \%$ ii) Y, Th, HREE, and P-enriched post-Cretaceous peralkaline complexes that intrude the Phanerozoic rocks of the southWestern Desert with REE amounting up to $2 \%$ and (3) upper Proterozoic, post-orogenic siderophyllite alkaline granite with REE amounting up to $0.8 \%$.

Gabal Shendib alkaline ring complex represents one of the largest alkaline rocks in the south Eastern Desert. It is located at the southern extremity of the Eastern Desert of Egypt near the Sudan Frontier and occupies the southern half of Elba topographic sheet (NF-37 I),(Fig. 1). It lies at a distance of about $45 \mathrm{~km}$ south of Abu-Ramad city. It is bound by Lat. $21^{\circ} 56^{\prime} 40^{\prime \prime}-22^{\circ} 06^{\prime} 22^{\prime \prime} \mathrm{N}$ and Long. $36^{\circ} 10^{\prime} 55^{\prime \prime}-36^{\circ} 23^{\prime} 12^{\prime \prime}$ E (Fig. 2).

Earlier authors, e.g. Ball (1912) studied the topography and geology of the south Eastern Desert, Egypt. Hume (1935) studied the fundamental Precambrian rocks of Egypt and Sudan. Takla et al., (1976) studied the tungsten deposits in seven occurrences located in Eastern Desert of Egypt (Qash Amir-Elba, G. Homeirat, Um Bisilla, Abu Kharif, El Dob, Fatira, El-Bedia and Abu Hammad). They concluded that the ore is enclosed mostly within small younger granite intrusions, which are intruded into metamorphosed country rocks including metasediments, metavolcanics and amphibolite.

Hussein (1977) summarized the regional geology of the northern Red Sea in Egypt and in Sudan. He also carried out some detailed field, petrographical and geochemical works

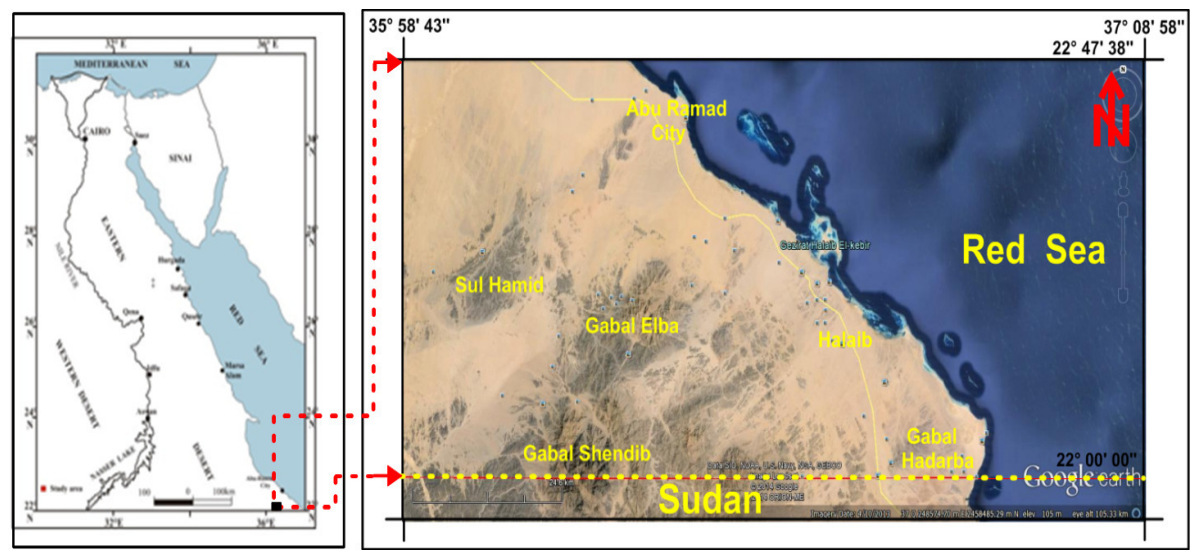

Fig.1: Location map and Google image of the studied area 


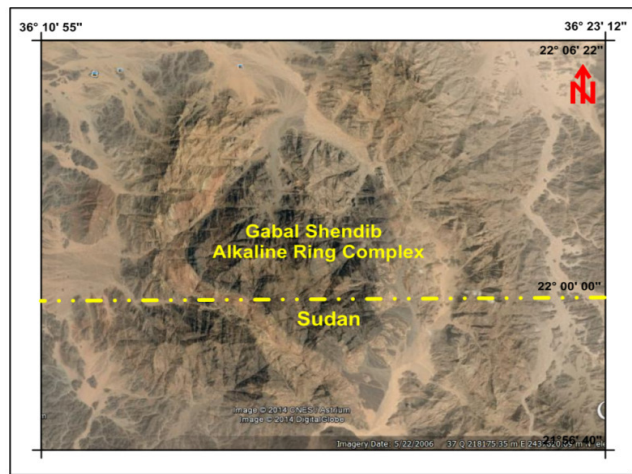

Fig.2: Close view of Google image for Gabal Shendib alkaline ring complex.

on the Sol Hamed complex and Halaib area. El-Alfy et al. (1994) geochemically explored the Elba-El Gerf area and he mentioned that there are a number of target areas that show anomalies of copper, nickel and chromium. Nasr and Youssef (1995) studied the Tertiary alkaline rocks in Gabal Elba area south Eastern Desert. They concluded that it may be Tertiary in age. El Agami et al. (1999) carried out mineralogical and geochemical studies on some mineralizaion in Halaib area, south Eastern Desert, Egypt. They concluded that the Mn-deposits of the granites and volcanic rocks in Halaib area are associated with tungsten and gold minerals, which were formed by hypogene hydrothermal solution.

Geological Survey of Egypt (1999) prepared geologic map on scale 1:250.000 for the basement rocks of Gabal Elba area between Lat. $22^{\circ} 00^{\prime}-23^{\circ} 00^{\prime}$. According to this map Gabal Shendib ignous complex composed essentially of alkaline granite, syenite and rhyolite.

Ibrahim (1999) studied the tectonic evaluation and uranium potentiality of Elba ring complex, south Eastern Desert. He concluded that Elba ring complex forms a concentric semicircular pluton composed of extrusive and intrusive rocks. The extrusive rocks were originated from an alkaline to subalkaline magma by fractional crystallization process. The plutonic rocks are reversely zoned margin of alkaline granites through an internal zone of alkaline syenite to core of gabbro.

Shahin (2000) studied the geology, petrography and geochemistry of Gabal Elba area. He concluded that the mapped area is identified into four tectonostratigraphic assemblages, namely oceanic rocks, arc related rocks, late to post collision granites and within plate alkaline ring complex, as well as some minor sheet intrusions represented by dykes and veins. The oceanic rocks represented by metagabbros and metabasalts. The arc related rocks include metavolcanics and tonalite-granodiorite rocks. The syn to late orogenic granites are represented by alkaline feldspar-rich granites. The within plate alkaline ring complex forms the core of the Gabal Elba.

Darwish (2003) studied the petrographic, geochemical and spectrometric investigation of the rock units and their mineralization of Gabal Elba area and Gabal Shendib complex, south Eastern Desert. He concluded that the rock units of Gabal Elba area can be grouped into three tectonic-stratigraphic units, namely i) arc assemblage which include metavolcanics (meta-andesite to metarhyolite) and older granite (tonalite-granodiorite), ii) post-orogenic granites which include younger granites (monzogranite and alkaline feldspar granite), iii) alkaline ring complex which include volcanics and associated pyroclastics (andesite to rhyolite), gabbros, alkaline syenite and alkaline granite.

Ibrahim et al. (2006) studied the mineralogy, spectrometry and geochemistry of manganese ore in Halaib area, south Eastern Desert. They concluded that most of the manganese ore of Gabal Elba occurs as veins or fracture filling cutting across the structure of the host rocks (Miocene sedimentary and monzogranite) indicating epigenetic mineralization often in multi-stages. The ore of Gabal Elba is composed of pyrolusite, cryp- 
tomelane and hollandite. They also concluded that the mineralization in Gabal Elba and Gabal Shendib represented mainly by secondary uranium (uranophane, beta-uranophane, kasolite and curite) and the associations (columbite, zircon, allanite, fluorite, zinwaldite and cassiterite).

Shahin (2014) study the Zr-Y-Nb-REE mineralization associated with microgranite and basic dykes at EL Sela shear zone, South Eastern Desert, Egypt. He concluded that these dykes hosting for uranium, rare metals $(\mathrm{Zr}, \mathrm{Y}, \mathrm{Nb}$ and $\mathrm{Ga})$ and light rare earths $(\mathrm{La}$, $\mathrm{Ce}, \mathrm{Sm}$ and $\mathrm{Nd}$ ) mineralizations.

This paper investigates principally the geology, geochemistry and radioactivity of Gabal Shendib alkaline ring complex, south Eastern Desert, Egypt.

\section{GEOLOGIC SETTING}

Gabal Shendib alkaline ring complex is a circular pluton reaching up to $12 \mathrm{~km}$ in di- ameter. The complex was emplaced within metavolcanics and tonalite-granodiorite host rocks. The outer part of the Shendib complex contains olivine gabbro, alkaline granite followed inwards by alkaline syenite. Remnants of the volcanic rocks represented by porphyritic trachyte, porphyritic rhyolite, rhyolite and tuffs occur in the southern part of the complex. A detailed geologic map was carried out on Gabal Shendib alkaline ring complex and the surrounding areas modified after Darwish (2003), (Fig.3).

\section{Arc Related Rocks}

\section{Metavolcanics}

The metavolcanics form a large extinction at Wadi Hareitra. These rocks range in color from dark green to grayish green color, massive, fine-grained, porphyritic, foliated, higly jointed and in some prats show highly schistose (Fig. 4). They are meta-andesite, meta-dacite and meta-rhyolite in composition. The associated meta-pyroclastics are of

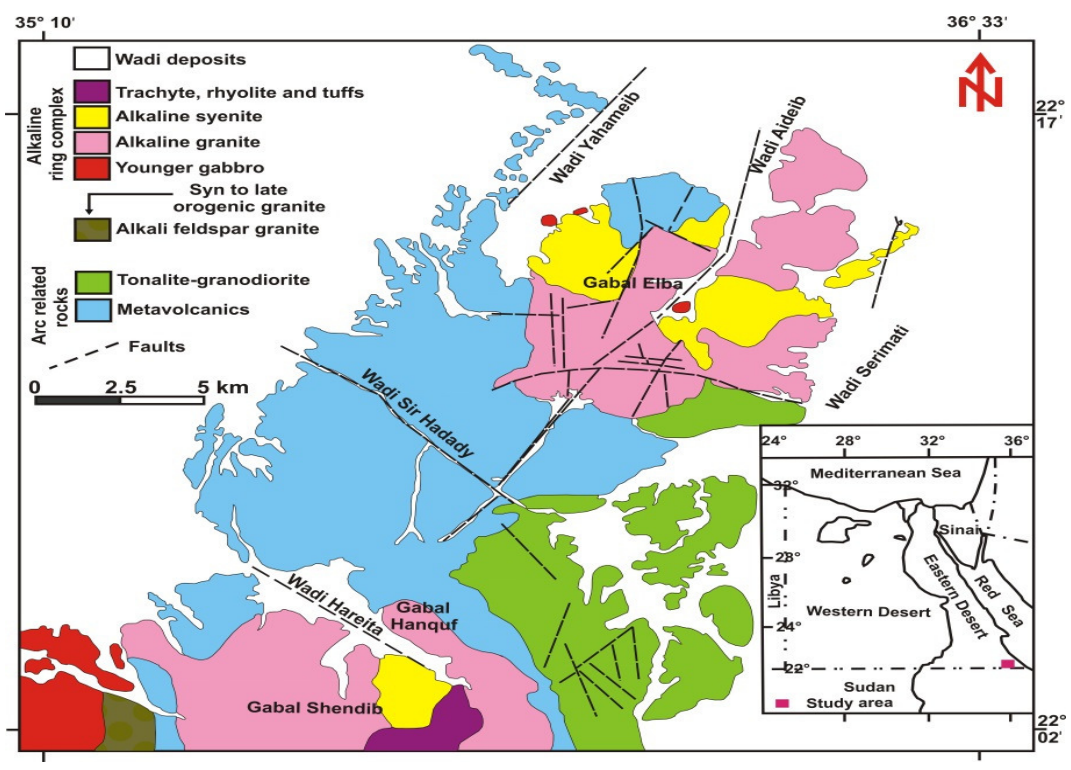

Fig.3: Geologic map of Gabal Shendib area, South Eastern Desert, Egypt (Modified after Darwish, 2003) 


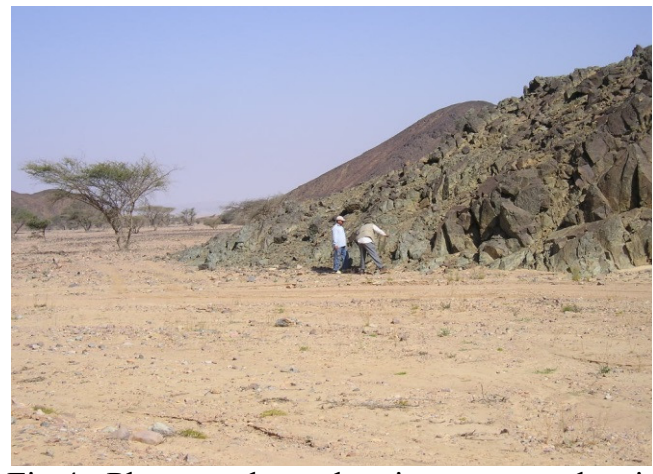

Fig.4: Photograph showing metavolcanic rocks at the front of Wadi Shendib, Looking SE

minor occurrence and mainly represented by meta-agglomerates, banded meta-crystal tuffs and tuffs. Field relations indicate that they are intruded by tonalite-granodiorite, alkaline granite and alkaline syenite with sharp contact.

\section{Tonalite-granodiorite}

Tonalite-granodiorite are massive, hard and in some parts show highly deformed and highly weathered especially near the contacts. They are gray to dark gray in color, medium to coarse grained, highly jointed, characterized by cavernous, exfoliation and bouldery weathering and hosting xenoliths of pre-existing rocks (Fig.5). They are characterized by cavernous, exfoliation and boulder weathering. Field relations indicate that they are intruded the metavolcanics and intruded by alkaline granite and alkaline syenite with sharp contact.

\section{Syn to Late Orogenic Granite}

\section{Alkali feldspar granite}

The syn to late orogenic rock is represented only by the alkali feldspar granite. It is exposed in small outcrop south west of Gabal Shendib complex. It is pink to red in color,

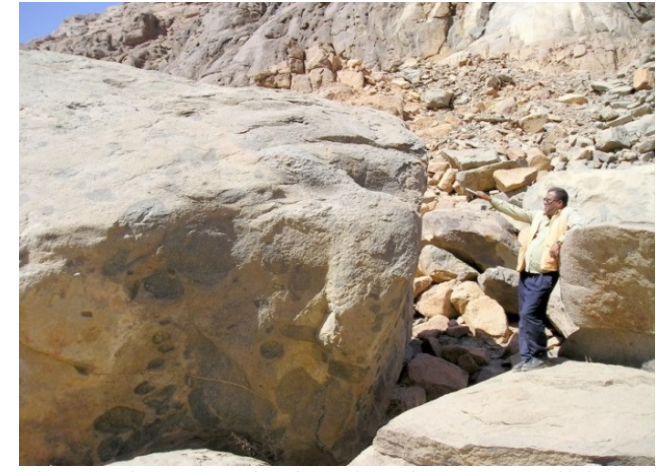

Fig.5: Photograph showing large xenoliths of pre-existing rocks in the granodiorite at Wadi Hiritra, Looking NW

medium to coarse-grained, highly weathered and highly jointed in some parts and massive in others. Field relation of this rock indicates that it intrudes the metavolcanics with sharp intrusive contact.

\section{Alkaline Ring Complex Younger gabbro}

Younger gabbros form very small occurrences in the studied area. They are found as large xenolithic bodies in alkaline granite and alkaline syenite. It is medium to coarse grained, very hard and range in color from deep green to greenish black. In some places, they are fractured and show exfoliation, spherical to subrounded bouldary weathering forming onion shape (Fig.6). Field relation of this rock indicates that it is enclosed in the syenite at the end of Wadi Aideib and subround bouldery weathering enclosed in alkali granites at wadi Yahameib.

\section{Alkaline granite}

The alkaline granite forms considerable area at Wadi Shendib. It occupies a terrain of moderate to high relief at Wadi Shendib and is bounded from south west by the metavolcanics. It is massive, medium to coarse grained 


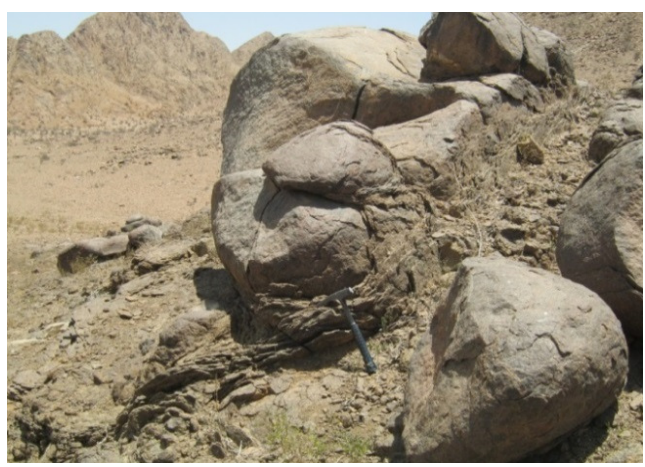

Fig.6: Photograph showing exfoliation, spherical to subrounded bouldary weathering forming onion shape in younger gabbro at core of Wadi Aideib, Looking S

and ranges in color from pink to pinkish white. These rocks are highly weathered and jointed in some places. They are traversed by more than one set of joints, the first one is $\mathrm{NE}$ and dipping $80^{\circ} / \mathrm{E}$ and the second trending $\mathrm{NW}$ and dipping $60^{\circ} / \mathrm{W}$. The alkaline granite shows a variable degree of weathering where in some places especially the high relief appears to be very massive whereas in other places especially the low relief appears to be highly weathered. Field relations reveal that it intrudes the arc related rocks with sharp intrusive contact (Figs.7\&8) and intruded by alkaline syenite with sharp contact at Wadi Shendib (Fig.9).

\section{Alkaline syenite}

The alkaline syenite forms a small outcrops in the studied area, occupying the core of the Gabal Shendib ring complex. It forms high relief terrains, massive, medium to coarse grained and ranges in color from reddish brown to red. This rock is highly jointed with NW direction and dipping nearly vertical.

\section{Volcanic Rocks}

The volcanic rocks in the studied area include porphyritic trachyte, porphyritic

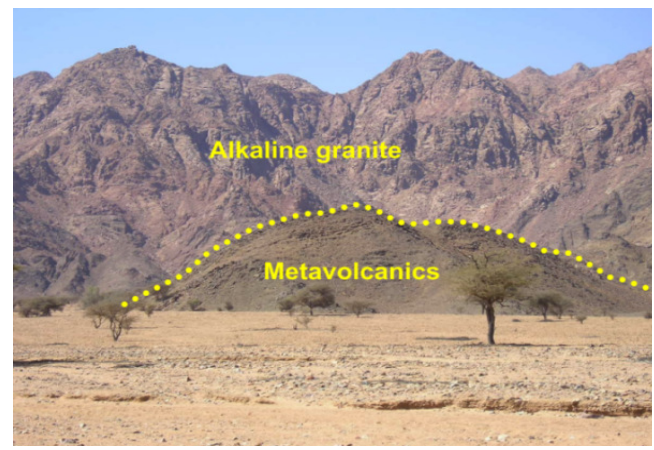

Fig.7: Photograph showing sharp contact between alkaline granite and metavolcanics, Looking SW

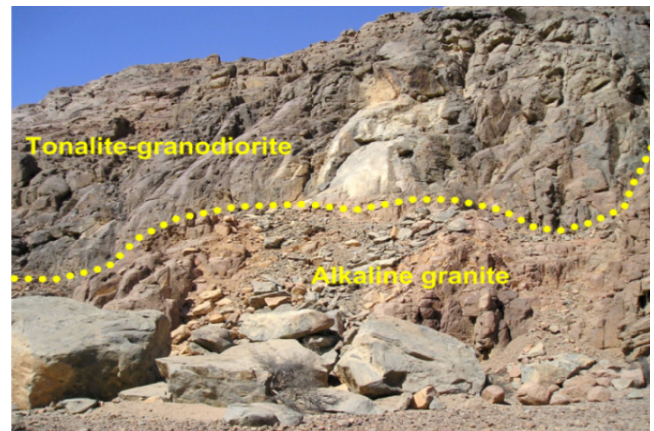

Fig.8: Photograph showing sharp contact between alkaline granite and tonalitegranodiorite, LookingW

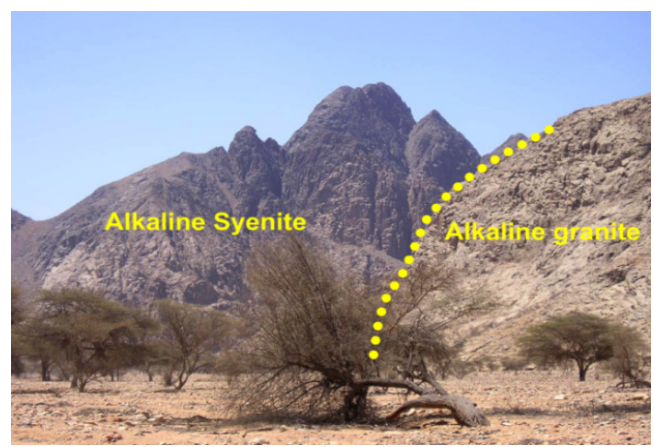

Fig.9: Photograph showing sharp contact between alkaline granite and alkaline syenite, Looking S 
rhyolite, rhyolite and tuffs. The alkaline trachyte porphyry is pale gray rocks showing pronounced trachytic texture. The rhyolite is characterized by subhorizontal flows associated with welded tuffs, breccias and agglomerates. Field relations indicate that this rock extrudes the alkaline syenite with sharp contact at the end of Wadi Shendib (Fig.10).

\section{PETROGRAPHY}

Petrographically, Gabal Shendib alkaline complex is composed mainly of olivine gabbro, alkaline granite, alkaline syenite and remnants of the volcanic rocks represented by porphyritic trachyte, porphyritic rhyolite, rhyolite and tuffs. The olivine gabbro exhibits hypidomorphic granular texture. It is composed of plagioclase, olivine, pyroxene and secondary amphiboles as well as opaques. The alkaline granite is hypidiomorphic, equigranular, porphyritic, coarse-grained and pink to reddish pink color. Microscopically, it is composed essentially of alkali feldspar comprises orthoclase and perthite, quartz, alkaline amphibole (arvedsonite and riebeckite), minor plagioclase and biotite. The accessory minerals are zircon, apatite and iron oxides. Orthoclase occurs as megacrysts up to $5.4 \mathrm{x}$ $2.2 \mathrm{~mm}$. Most of the orthoclase crystals show

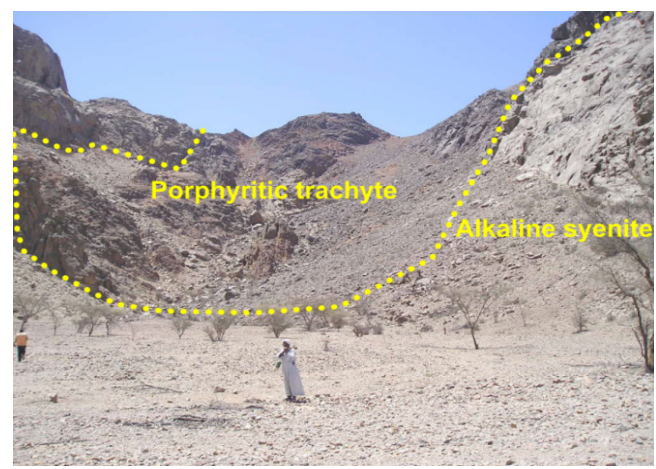

Fig.10: Photograph showing alkaline syenite extruded by porphyritic trachyte rock, Looking S perthitic texture and still persevered the simple twinning (Fig.11). Perthite occurs as subhedral megacrysts up to $3.7 \times 2.3 \mathrm{~mm}$. Perthitic veinlets are the most predominate type of perthite in this granite (Fig.12). Quartz occurs as subhedral to anhedral small crystals up to $0.1 \times 0.2 \mathrm{~mm}$. It is found in two generations, the older fills the interstices between the K-feldspar crystals, whereas the younger appears as intergrowth with perthite crystals forming graphic and myrmeckitic textures (Figs.13\&14). Arvedsonite and riebeckite represent the chief alkaline mafic amphibole minerals. It occurs as subhedral to anhedral crystals. It is characterized by its green color and strongly pleochroic (Figs.15\&16).

The alkaline syenite of Gabal Shendib alkaline complex is composed essentially of alkali feldspars (orthoclase and perthite) and clots of alkali pyroxene. Under the microscope, the alkali feldspar occurs as tabular, euhedral to subhedral crystals (Fig.17). Aegirine augite is the chief mafic constituent occurs as subhedral tabular crystals (Fig.18). Some aegirine augite crystals show alteration to arfvedsonite and riebeckite (Figs.19\&20). Sphene, apatite and opaques are accessory minerals.

The porphyritic rhyolite is composed of quartz and sanidine phenocrysts and laths of perthite orthoclase embedded in cryptocrystalline being composed of fine laths of quartz, sanidine, biotite, chlorite and iorn oxides (Fig. 21). The porphyritic trachyte is pale gray color showing trachytic texture. The rock is composed mainly of sanidine phenocrysts and laths of perthitic orthoclase. The groundmass is composed of perthitic orthoclase and small flakes of biotite (Fig.22).

\section{MINERALOGICAL INVESTIGATIONS}

The mineralogical studies of the alkaline granite and alkaline syenite were performed on whole rock samples and separated mineral grains by petrographic microscope. Electron-Scanning Microscope (SEM) supported 


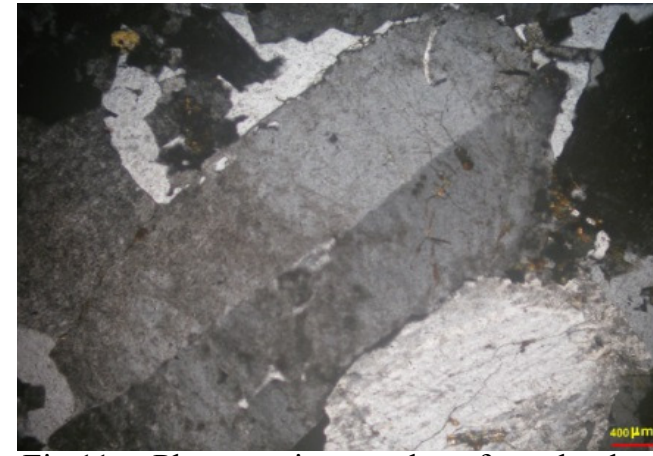

Fig.11: Photo micrograph of orthoclase perthite showing simple twinning in the studied alkaline granite, XPL

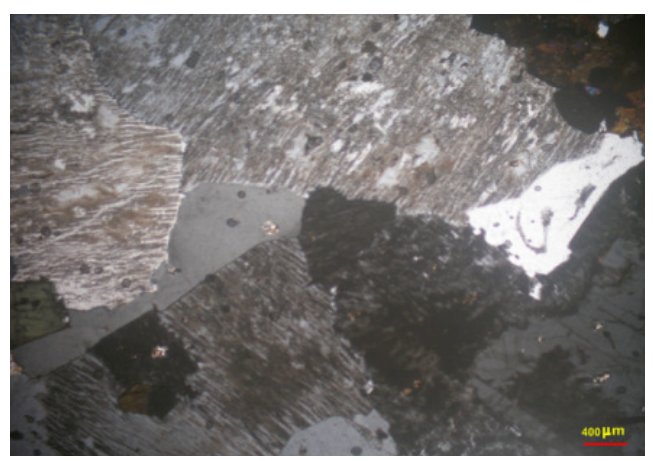

Fig.12: Photomicrograph of perthite megacrysts showing perthitic veinlets in the studied alkaline granite, XPL

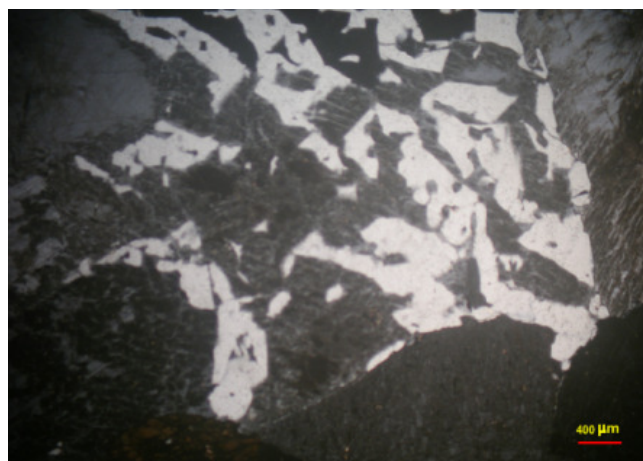

Fig.13: Photo micrograph of quartz and perthite crystal showing graphic texture in the studied alkaline granite, XPL

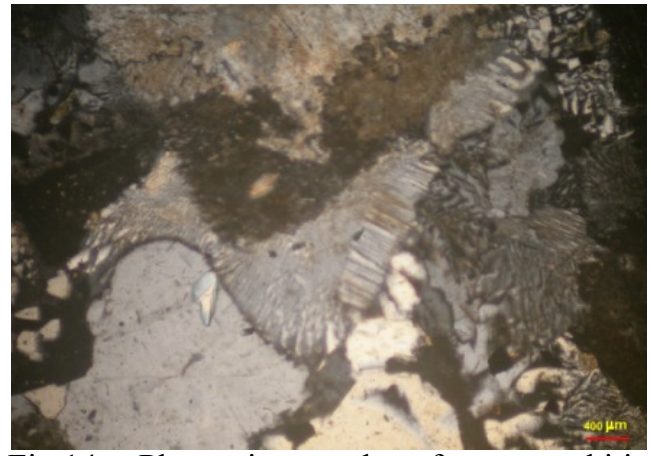

Fig.14: Photomicrograph of myrmeckitic textures in the studied alkaline granite, XPL

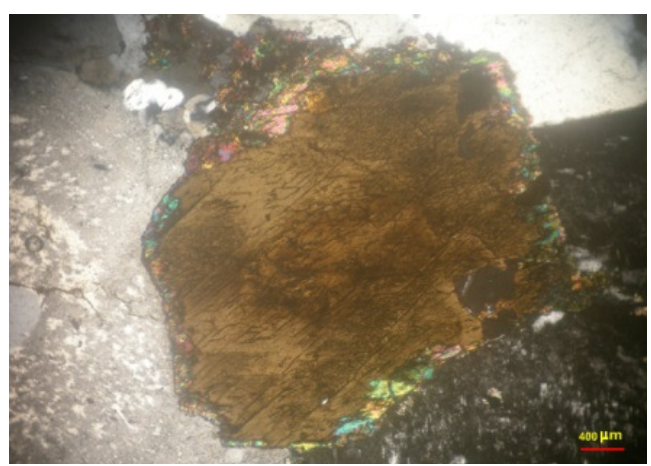

Fig.15: Photomicrograph of arvedsonite crystal with peripheral aegirine-augite in the studied alkaline granite, XPL

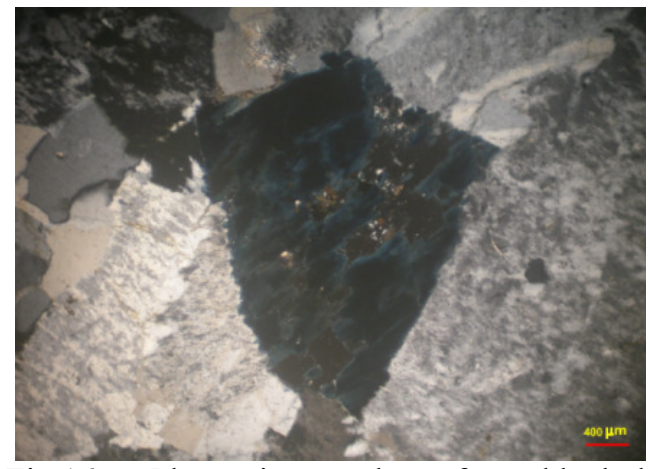

Fig.16: Photomicrograph of subhedral riebeckite crystal surrounded by perthite crystals in the studied alkaline granite, XPL 


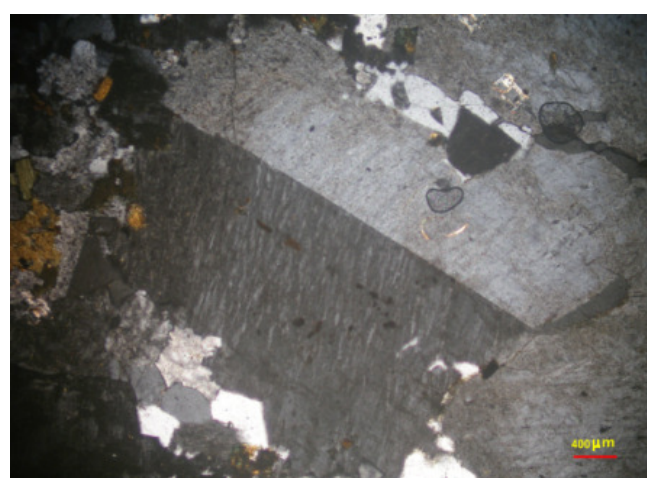

Fig.17: Photomicrograph of orthoclase perthite crystal showing simple twinning in the alkaline syenite, XPL

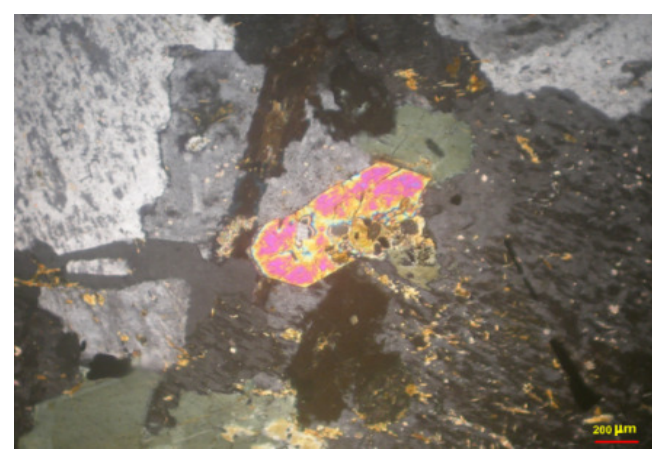

Fig.18: Photomicrograph of euhedral studied aegirine-augite crystal surrounded by perthite crystals in the alkaline syenite, XPL

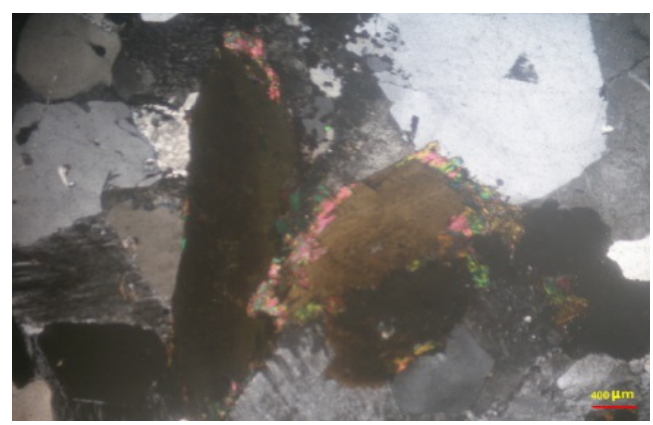

Fig.19: Photomicrograph of subhedral crystal in arfvedsonite with perephral aegirine-augite in the studied alkaline syenite, XPL

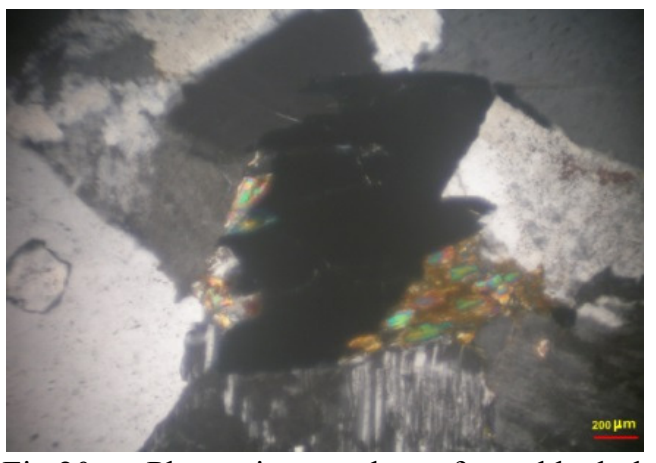

Fig.20: Photomicrograph of subhedral riebeckite crystal with peripheral aegirineaugite in the studied alkaline syenite, XPL

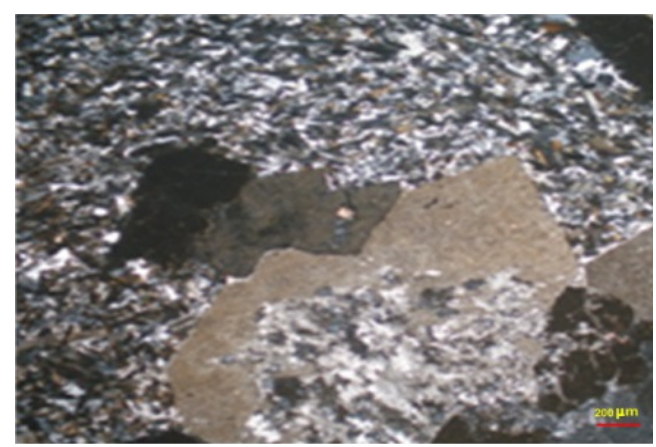

Fig.21: Photomicrograph of orthoclase perthite showing simple twinning in the studied porphyritic rhyolite, XPL

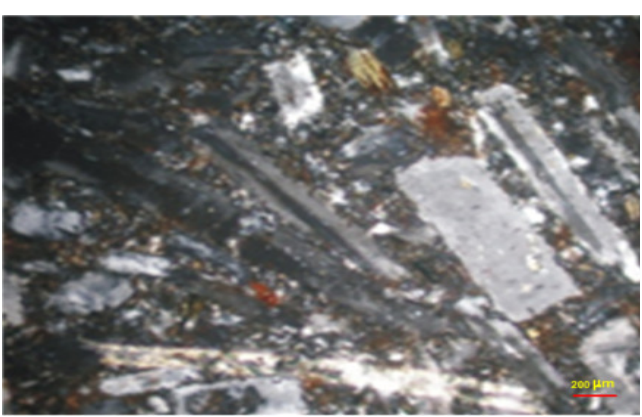

Fig.22: Photomicrograph of euhedral sanidine phenocrysts showing trachytic texture in the studied porphyritic trachyte, XPL 
by EDX. Scanning electron microscope (SEM) with a back-scattered electron imaging (BSE) of the alkaline rocks of Gabal Shendib ring complex show that these rocks host to a numerous small mineral occurrences include some rare metal contents $(\mathrm{Zr}, \mathrm{Nb}, \mathrm{Y})$ and rare earths (La, Ce, Pr, Nd, Sm, Gd, Dy) elements. Radioactive minerals include uranophane and thorianite are also identified. Results of detailed mineralogical examination of these elements have been identified as follow:

\section{Uranophane}

Uranophane is identified as individual anhedral grains in the studied alkaline granite, which range in color from lemon yellow to pale yellow. The most common impurity in this uranofane mineral is iorn oxide. Backscattered electron (BSE) image of uranophane crystal showed uranophane crystal with matted intergrowth of minute fibers (Fig.23). Uranophane occurs as thin coatings on sodic feldspar minerals impling that the uranophane was added during the latest magmatic stage of the magma crystallization (Fig.24).

\section{Urnothorite}

Urnothorite occurs as individual minute grains up to $200 \mu \mathrm{m}$ in size either as intergrowth with feldspars or inclusions in zircon in the studied alkaline granite (Fig.25).

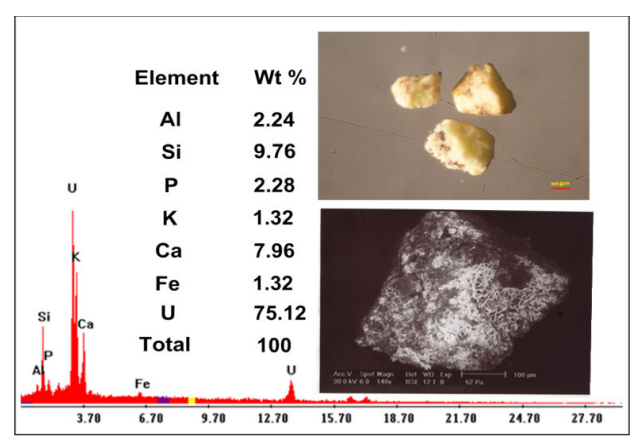

Fig.23: EDS spectrum, BSE image and photomicrograph showing semi-quantitative chemical composition of uranophane

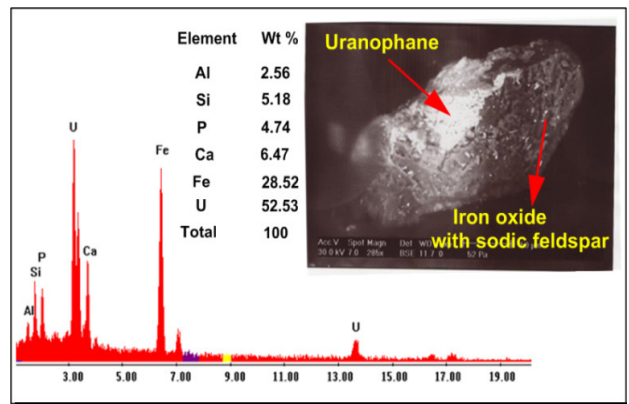

Fig.24: EDS spectrum and BSE image of sodic feldspar coated by minute grains of uranophane

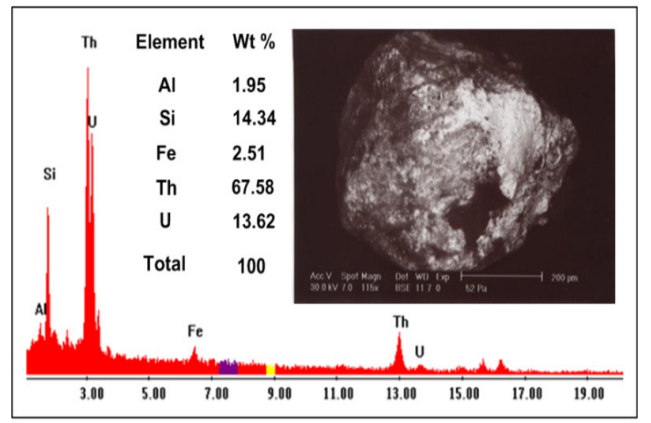

Fig.25: EDS spectrum and BSE image showing semi-quantitative chemical composition of urnothorite

\section{Xenotime}

Xenotime occurs as minute grains or as extremely thin coatings on zircon grains in the studied alkaline granite (Fig.26). The occurrence of xenotime at rim of zircon crystals implying that the xenotime was added during the latest magmatic stage of the magma crystallization.

\section{Zircon}

Zircon was found as the most abundant accessory mineral in the studied alkaline rocks of Gabal Shendib ring complex. Two types of zircon were distinguished from the studied sam- 


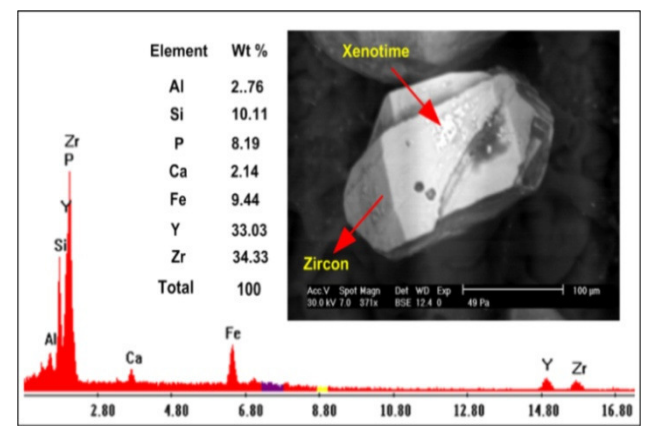

Fig.26: EDS spectrum and BSE image showing semi-quantitative chemical composition of xenotime mineral coatings on magmatic zircon

ples: primary magmatic zircon and metamict zircon. The magmatic zircon occurs in both alkaline rocks of Gabal Shendib as suhedral to euhedral prismatic colorless grains with bipyramidal terminations intergrown up to 200 $\mu \mathrm{m}$ in size (Fig.27). In the studied alkaline granite, zircon crystals are mainly characterized by considerable metamictization, due to the presence of uranium and thorium minerals (Fig.28). Scanning electron microscopy for zircon crystals revealed that xenotime occurs as minute grains or as extremely thin coatings on zircon grains (Fig.26).

\section{Allanite}

Allanite is an epidote-group mineral characterized by an abundant LREE, which can incorporate weight percents of the light rare earth elements (LREE) La, Ce and Nd.Backscattered electron (BSE) image of allaniteshows minute grains or extremely thin coatings on the feldspar minerals of the studied alkaline syenite indicating that allanite was added during the latest magmatic stage of the magma crystallization (Fig. 29).

\section{Monazite}

Monazite is a phosphate mineral containing high percents of light rare earth elements (La, Ce). It occurs usually in small

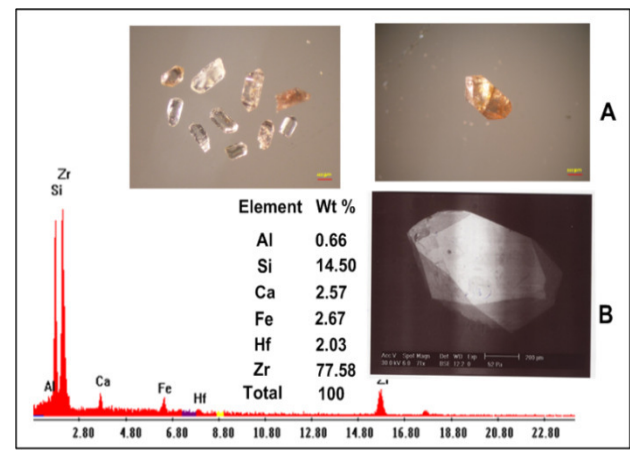

Fig.27: EDS spectrum, BSE image and photomicrograph showing semi-quantitative chemical composition of primary magmatic zircon

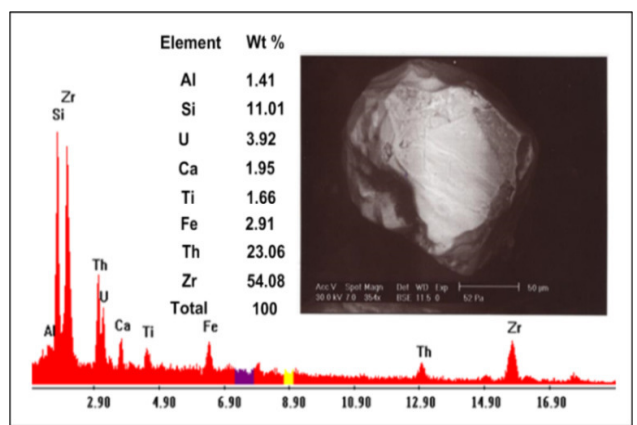

Fig.28:EDS spectrum andBSE image showing semi-quantitative chemical composition of metamict zircon

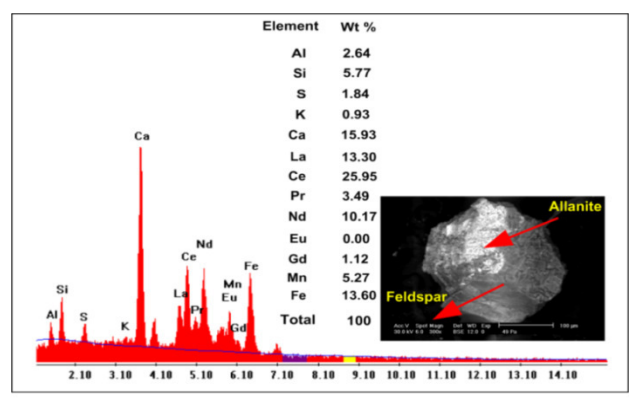

Fig. 29: EDS spectrum and BSE image showing semi-quantitative chemical composition of allanite coatings on feldspar grains 
isolated crystals. Monazite is radioactive due to the presence of thorium and, less commonly, uranium, (Fig.30).

\section{Ferrocolumbite}

Ferrocolumbite grains were detected in the studied samples of the alkaline granite of Gabal Shendib alkaline ring complex. The grains are generally black in color with brilliant metallic luster under the transmitted light of an optical microscope. Th grains are usually characterized by the presence of $U$ and Th (Fig.31).

\section{Apatite}

Apatite occurs in the form of massive, euhedral to subhedral grains with size up to $50 \mu \mathrm{m}$ in the studied alkaline rocks. The apatite crystals are generally light gray in color under the transmitted light of an optical microscope. Back-scattered electron (BSE) image of apatite showed two occurrence of apatite, the first one occurs as euhedral to subhedral primary magmatic grains (Fig.32), the second occurs as extremely thin coatings on the feldspar and quartz minerals, indicating that apatite was added during the latest magmatic stage of the magma crystallization (Fig.33).

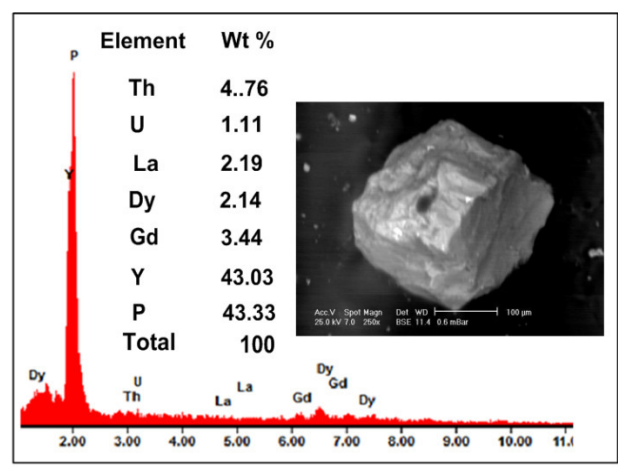

Fig.30: EDS spectrum and BSE image showing semi-quantitative chemical composition of monazite

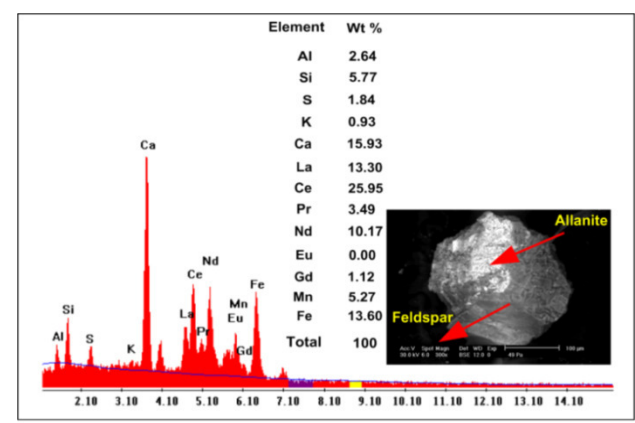

Fig.31: EDS spectrum and BSE image showing semi-quantitative chemical composition of ferrocolumbite mineral

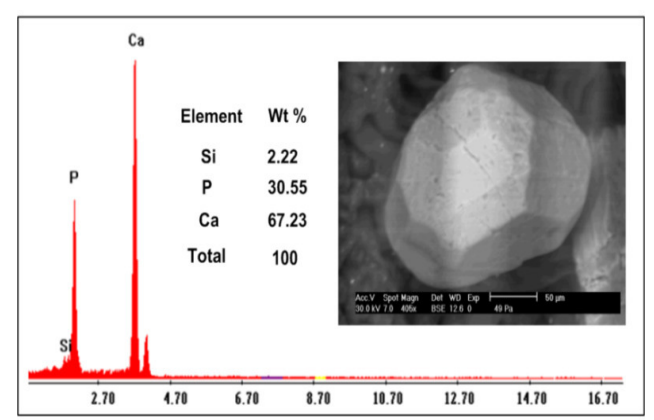

Fig.32: EDS spectrum and BSE image showing semi-quantitative chemical composition of apatite

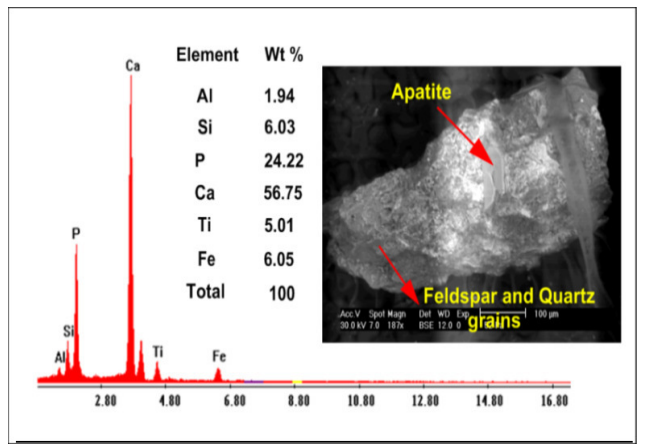

Fig.33: EDS spectrum and BSE image showing semi-quantitative chemical composition of apatite associated with feldspar and quartz minerals 


\section{Titanite}

Titanite is one of the most common accessory minerals occurring in the studied alkaline rocks. It occurs as rod or rhombic

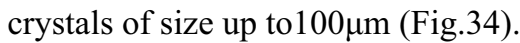

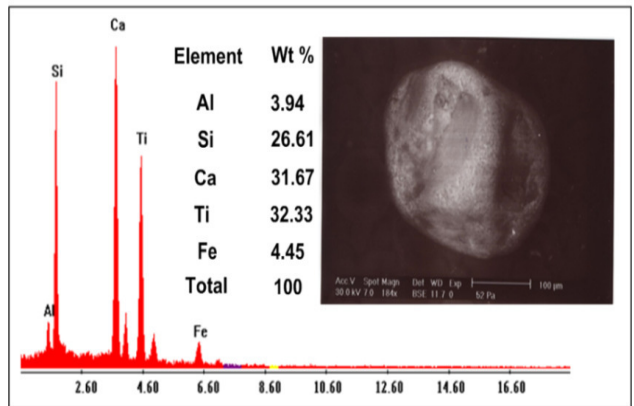

Fig.34: EDS spectrum and BSE image showing semi-quantitative chemical composition of titanite

\section{RADIOMETRIC INVESTIGATION}

Detailed field radiometric measurements using a portable four channel, gamma-ray spectrometer Model GR-230 was carried out along Gabal Shendib alkaline ring complex. The detailed field radiometric measurements revealed that low uranium content associated with alkaline granite and alkaline syenite. Radioactivity level was found to vary from $0.6 \mathrm{ppm}$ to $13.7 \mathrm{ppm}(\mathrm{eU})$ in alkaline granite and from $0.6 \mathrm{ppm}$ to $4.90 \mathrm{ppm}$ eU in alkaline syenite.

The statistical treatment of spectrometric data was expressed on binary diagrams of $\mathrm{eTh}$ versus $\mathrm{eU}, \mathrm{eU}$ versus $\mathrm{eU} / \mathrm{eTh}$ and $\mathrm{eU}$ versus eU- eTh/3.5 (Fig. 35). Radiometric Data for alkaline granite and alkaline syenite are are listed in Table (1).

\section{MATERIALS AND METHODOLOGY}

Thirty samples from the fresh Gabal Shendib alkaline complex were collected for
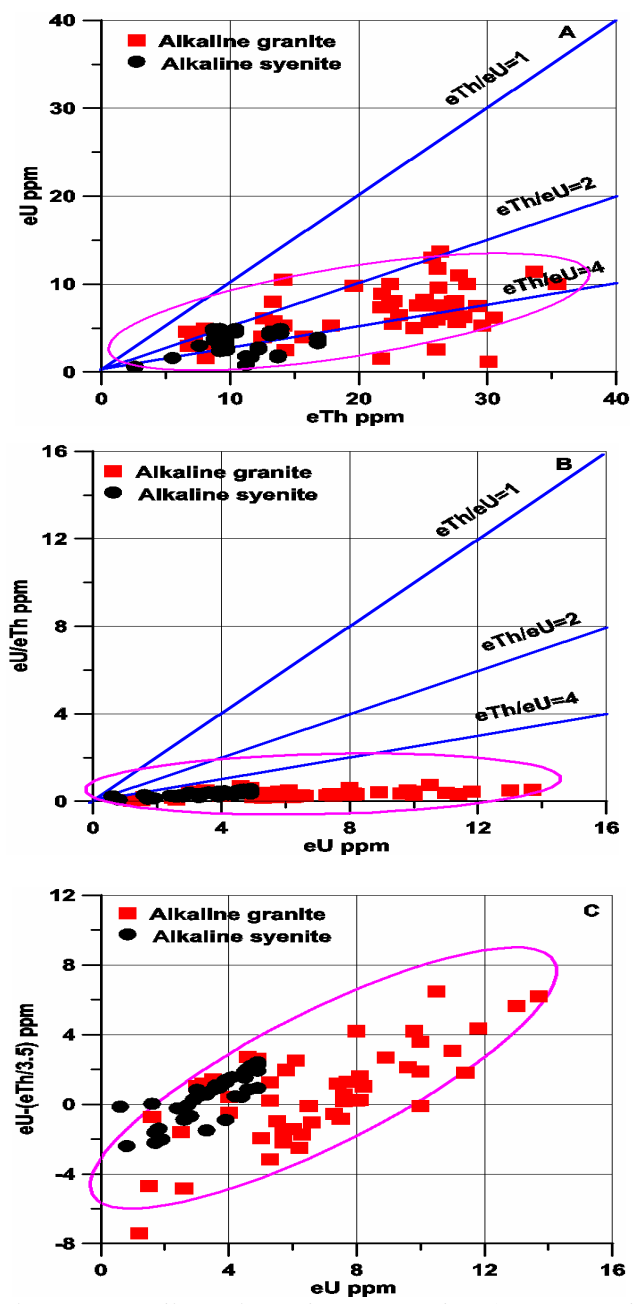

Fig. 35: Radioactive elements plot for ground gamma-ray spectrometry measurements for the studied alkaline granite and alkaline syenite A) eTh versus eU, B) eU versus eU/ eTh and C) Mobility

Table 1: Radiometric measurements of the studied alkaline granite and alkaline syenite

\begin{tabular}{|c|c|c|c|c|c|c|c|c|c|c|c|c|}
\hline \multirow{2}{*}{ Rock type } & \multicolumn{4}{|c|}{ Total Count } & \multicolumn{2}{|c|}{$\mathrm{K}(\%)$} & \multicolumn{3}{|c|}{$\mathrm{eU}(\mathrm{ppm})$} & \multicolumn{3}{|c|}{ eTh (ppm) } \\
\hline & Min. & Max. & Aver. & Min. & Max. & Aver. & Min. & Max. & Aver. & Min. & Max. & Aver. \\
\hline $\begin{array}{l}\text { alkaline } \\
\text { granite (N=51) }\end{array}$ & 17.60 & 48.20 & 33,34 & 1.70 & 7.50 & 5.12 & 0.8 & 13.70 & 6.15 & 4.00 & 35.40 & 19.60 \\
\hline $\begin{array}{l}\text { Allkaline } \\
\text { syenite (N=38) }\end{array}$ & 12.70 & 32.30 & 25.29 & 3.30 & 6.50 & 5.15 & 0.6 & 4.90 & 332 & 2.60 & 16.80 & 10.07 \\
\hline
\end{tabular}


this study. From these, twenty samples were selected for thin sections to study the mineral constituents of these granite and syenite. Ten samples were selected and chemically analyzed for their trace elements and REE by $\mathrm{X}$-ray fluorescence analyzer (XRF) and inductively coupled plasma mass spectrometry (ICP-MS). The analyses were performed in the Nuclear Materials Authority Analytical Laboratories. Data of the trace elements and rare earth elements of the studied granite and syenite are listed in Tables (2\&3).

\section{GEOCHEMISTRY}

\section{Major and Trace Elements}

The alkaline rocks of Gabal Shendib ring complex show high contents of $\mathrm{Na}_{2} \mathrm{O}(4.5-$ $5.85 \%), \mathrm{K}_{2} \mathrm{O}(4.5-5.98 \%)$ and low contents of $\mathrm{CaO}(1.02-1.70 \%), \mathrm{MgO}(0.10-2.00 \%)$, $\mathrm{Fe}_{2} \mathrm{O}_{3}(2.20-2.90 \%)$ and $\mathrm{TiO}_{2}(0.66-.90 \%)$, (Table 2).
$\mathrm{SiO}_{2}$ versus $\mathrm{K}_{2} \mathrm{O}$ diagram after Middlemost (1975) is used. This figure indicate that the most samples of the alkaline granite display medium-k to relatively high- $\mathrm{k}$, while the alkaline syenite show high potassium character (Fig. 36).

From the $\mathrm{Al}_{2} \mathrm{O}_{3} /\left(\mathrm{CaO}+\mathrm{Na}_{2} \mathrm{O}+\mathrm{K}_{2} \mathrm{O}\right)$ versus $\mathrm{Al}_{2} \mathrm{O}_{3} /\left(\mathrm{Na}_{2} \mathrm{O}+\mathrm{K}_{2} \mathrm{O}\right)$ diagram, after Maniar and Piccoli (1989), (Fig. 37). It is indicating that the majority of samples have peralkaline characters. From the Agpaitic index $(\mathrm{AI}=$ $\mathrm{Na}+\mathrm{K} / \mathrm{Al}$ ) versus $\mathrm{SiO}_{2}$ diagram, the majority of samples have agpatic index $(\mathrm{AI}=\mathrm{Na}$ $+\mathrm{K} / \mathrm{Al}$ ) $>1$ (Fig. 38) and are thus classified as peralkaline granites according to Lie'geois and Black (1987). On the $(\mathrm{Na}+\mathrm{K}) / \mathrm{Al}$ versus $\mathrm{Zr}$ (ppm) diagram of the peralkaline plutons (Fig. 39), after Shellnutt \& Zhou (2007) and Shellnutt et al. (2009a), most of the studied samples occur in the peralkaline field. The $\mathrm{K}-\mathrm{Rb}$ diagram (Fig. 40) shows that the magmatic trend (1000-100 MT) is given by Shaw

Table 2 : Major oxides (wt. \%) and trace element data (ppm) of the studied alkaline granite and alkaline syenite rocks

\begin{tabular}{|c|c|c|c|c|c|c|c|c|c|c|}
\hline \multirow{2}{*}{ S. No. } & \multicolumn{5}{|c|}{ Alkaline granite } & \multicolumn{5}{|c|}{ Alkaline syenite } \\
\hline & $\operatorname{Sh} 2$ & Sh6 & Sh9 & Sh10 & Sh13 & Sh5 & Sh7 & Sh8 & Sh12 & Sh14 \\
\hline $\mathrm{SiO}_{2}$ & 71.40 & 70.10 & 70.40 & 69.9 & 70.3 & 55.20 & $\mathbf{5 8 . 4 0}$ & 56.30 & 58.00 & 54.80 \\
\hline $\mathrm{TiO}_{2}$ & 0.66 & 1.90 & 0.63 & 0.65 & 0.75 & 1.02 & 0.12 & 1.06 & 1.03 & 1.06 \\
\hline $\mathbf{A l}_{2} \mathbf{O}_{3}$ & 12.13 & 12.20 & 12.65 & 12.4 & 12.4 & 16.65 & 16.50 & 16.25 & 16.35 & 16.50 \\
\hline $\mathrm{Fe}_{2} \mathrm{O}_{3}$ & 2.60 & 2.20 & 2.23 & 2.80 & 2.90 & 2.70 & 2.42 & 2.54 & 2.63 & 2.45 \\
\hline MnO & 0.26 & 0.70 & 0.30 & 0.42 & 0.21 & 0.70 & 0.40 & 0.50 & 0.65 & 0.90 \\
\hline MgO & 2.00 & 0.10 & 0.55 & 0.30 & 0.45 & 0.60 & 0.55 & 0.40 & 0.50 & 0.56 \\
\hline $\mathrm{CaO}$ & 1.04 & 1.02 & 1.08 & 1.7 & 1.08 & 1.20 & 1.40 & 1.35 & 1.22 & 1.30 \\
\hline $\mathrm{Na}_{2} \mathrm{O}$ & 4.60 & 4.70 & 4.65 & 4.50 & 4.40 & 5.50 & 5.85 & 5.75 & 5.65 & 5.20 \\
\hline $\mathbf{K}_{2} \mathbf{O}$ & 4.50 & 4.80 & 4.72 & 4.6 & 4.7 & 5.90 & 5.98 & 5.95 & 5.93 & 5.70 \\
\hline $\mathbf{P}_{2} \mathbf{O}_{5}$ & 0.01 & 0.08 & 0.11 & 0.12 & 0.13 & 0.06 & 0.03 & 0.08 & 0.04 & 0.08 \\
\hline $\begin{array}{l}\text { LOI } \\
\text { Total }\end{array}$ & $\begin{array}{r}0.80 \\
100\end{array}$ & o.80 & $\begin{array}{r}0.30 \\
99.40\end{array}$ & $\begin{array}{r}0.31 \\
99.69\end{array}$ & $\begin{array}{r}0.33 \\
100\end{array}$ & $\begin{array}{r}2.10 \\
99.28\end{array}$ & $\begin{array}{r}1.20 \\
100.03\end{array}$ & $\begin{array}{r}0.29 \\
100.29\end{array}$ & $\begin{array}{r}0.40 \\
100.07\end{array}$ & $\begin{array}{r}0.80 \\
100\end{array}$ \\
\hline A/CNK & 0.81 & 0.79 & 0.82 & $\begin{array}{r}0.78 \\
9.78\end{array}$ & 0.83 & 0.89 & 0.85 & 0.85 & 0.87 & 0.92 \\
\hline A/NK & 0.89 & 0.86 & 0.91 & 0.92 & 0.92 & 0.98 & 0.94 & 0.93 & 0.95 & 1.02 \\
\hline \multicolumn{11}{|c|}{ Trace elements (ppm) } \\
\hline $\mathrm{Cr}$ & 28 & 35 & 68 & 31 & 30 & 89 & 139 & 196 & 106 & 38 \\
\hline $\mathbf{N i}$ & 6 & 8 & 4 & 7 & 11 & 9 & 5 & 4 & 4 & 11 \\
\hline $\mathbf{C u}$ & 10 & 10 & 10 & 11 & 12 & 10 & 16 & 11 & 9 & 9 \\
\hline $\mathbf{Z n}$ & 73 & 136 & 77 & $\mathbf{7 4}$ & 79 & 124 & 181 & 124 & 71 & 95 \\
\hline $\mathbf{Z r}$ & 816 & 1303 & 666 & 680 & 809 & 1510 & 987 & 1544 & 723 & 4527 \\
\hline $\mathbf{R b}$ & 49 & 151 & 133 & 127 & 78 & 148 & 64 & 158 & 112 & 78 \\
\hline $\mathbf{Y}$ & 493 & 806 & 296 & 415 & 497 & 665 & 320 & 498 & 235 & 270 \\
\hline Ba & 95 & 83 & 79 & 98 & 88 & 317 & 280 & 310 & 282 & 290 \\
\hline Pb & 9 & 8 & 11 & 7 & 12 & 11 & 58 & 26 & 11 & 9 \\
\hline $\mathrm{Sr}$ & 29 & 46 & 24 & 25 & 29 & 54 & 8 & 7 & 8 & 11 \\
\hline Ga & 25 & 22 & 6 & 24 & 23 & 6 & 113 & 63 & 12 & 41 \\
\hline $\mathbf{V}$ & 3 & 3 & 14 & 12 & 20 & 7 & 333 & 12 & 51 & 621 \\
\hline Nb & 110 & 138 & 137 & 144 & 130 & 275 & 142 & 222 & 104 & 717 \\
\hline $\mathbf{U}$ & 10 & 35 & 15 & 8 & 5 & 7 & 10 & 15 & 7 & 8 \\
\hline $\mathbf{K} / \mathbf{R b}$ & 762 & 264 & 295 & 301 & 500 & 331 & 776 & 313 & 440 & 607 \\
\hline $\mathbf{R b} / \mathbf{S r}$ & 1.69 & 3.28 & 5.54 & 5.08 & 2.69 & 2.74 & 8.00 & 22.57 & 14 & 7.09 \\
\hline
\end{tabular}

Note: $\mathrm{A} / \mathrm{CNK}=$ molar ratio of $\mathrm{Al}_{2} \mathrm{O}_{3} /\left(\mathrm{CaO}+\mathrm{Na}_{2} \mathrm{O}+\mathrm{K}_{2} \mathrm{O}\right), \mathrm{A} / \mathrm{NK}=$ molar ratio of $\mathrm{Al}_{2} \mathrm{O}_{3} /\left(\mathrm{Na}_{2} \mathrm{O}+\mathrm{K}_{2} \mathrm{O}\right)$ 


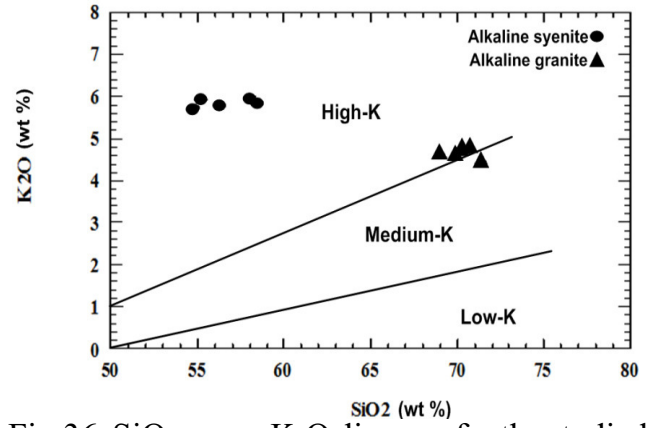

Fig.36: $\mathrm{SiO}$ versus $\mathrm{K} \mathrm{O}$ diagram for the studied alkaline rocks, after Middlemost (1975)

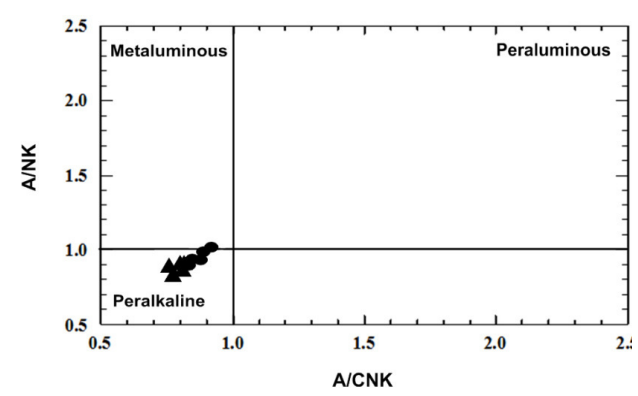

Fig.37: Shand's index diagram for studied alkaline rocks of Gabal Shendib ring complex. Fields after Maniar and Piccoli (1989), (Symbols as on Fig. 36)

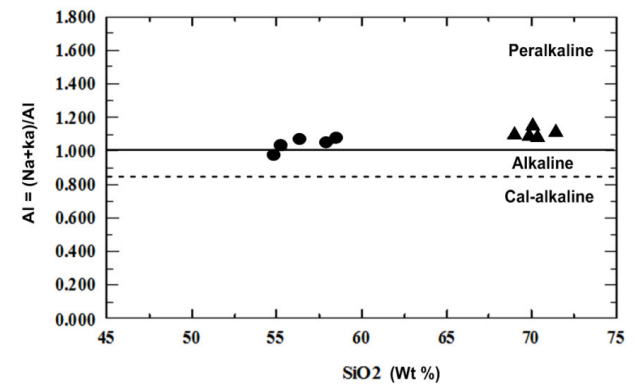

Fig.38: Agpaitic index $(\mathrm{AI}=\mathrm{Na}+\mathrm{K} / \mathrm{Al})$ versus $\mathrm{SiO}_{2}$ diagram showing the alkaline to peralkaline characters of the studied alkaline rocks. Note that the line with $\mathrm{AI}=0.87$ (Lie'geois and Black, 1987) separates alkaline and calc-alkaline granite series (Symbols as on Fig. 36)

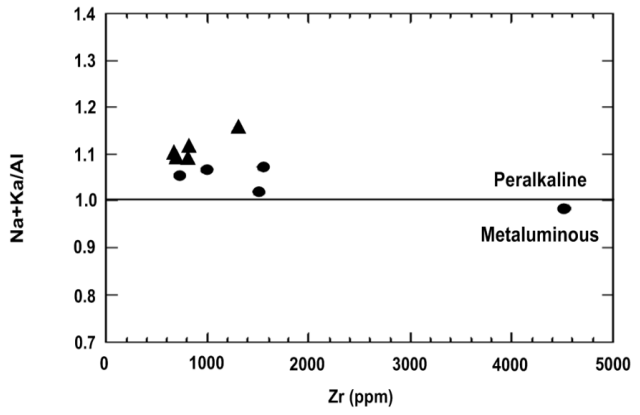

Fig.39: $(\mathrm{Na}+\mathrm{K}) / \mathrm{Al}$ versus $\mathrm{Zr}$ diagram of the peralkaline plutons. Data from Shellnutt \& Zhou, (2007) and Shellnutt et al. (2009a), (Symbols as on Fig. 36)

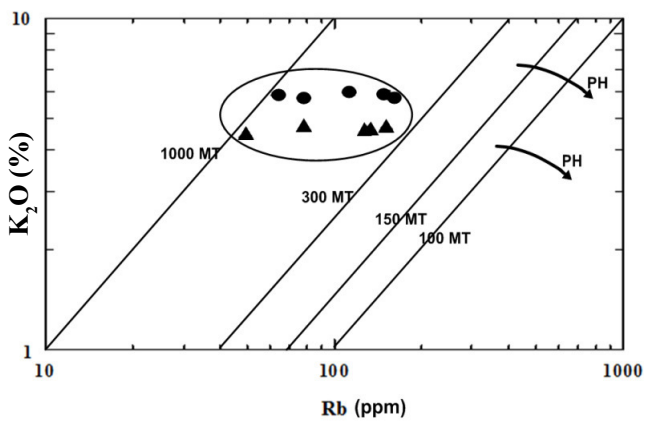

Fig.40: K-Rb variation diagram for the studied alkaline rocks of Gabal Shendib ring complex (After Shaw, (1968), crustal K/Rb ratio (After Taylor, (1965), (Symbols as on Fig. 36)

(1968), while the average crustal $\mathrm{K} / \mathrm{Rb}$ ratio is 250 (Taylor, 1965). The alkaline granite and alkaline syenite of Gabal Shendib ring complex samples plotted between the magmatic trend (300-1000 MT) is given by Shaw (1968) and near the average crustal K/Rb 250 of Taylor (1965). The computed $\mathrm{K} / \mathrm{Rb}$ ratio decreases from the alkaline syenite $(776 \mathrm{ppm})$ to the alkaline granite (264 ppm). The lower $\mathrm{K} / \mathrm{Rb}$ ratios in the alkaline syenite indicate more differentiated and more evolved magmatic liquids.

From the K-Ba variation diagram of Ma- 
son, (1966) who is determine the crustal average ratio $(\mathrm{K} / \mathrm{Ba}=65)$, the plot of the studied alkaline granite and alkaline syenite samples occur above the average crustal ratio with $\mathrm{K} / \mathrm{Ba}$ ratio $(>65)$, showing $\mathrm{Ba}$ depletion with $\mathrm{K}_{2} \mathrm{O}$ enrichment which indicates highly fractional crystallization lead to the enrichment of $\mathrm{K}_{2} \mathrm{O}$ in residual melts (Fig.41). Early precipitation of $\mathrm{Ba}$ is reciprocal to the behavior of $\mathrm{Rb}$, and the $\mathrm{Ba} / \mathrm{Rb}$ ratio rates as one of the most sensitive indicators of fractionation (Taylor \&Heier 1960; Taylor,1963). The $\mathrm{Rb}-\mathrm{Ba}$ variation diagram of Mason (1966) shows that $\mathrm{Ba}$ is depleted

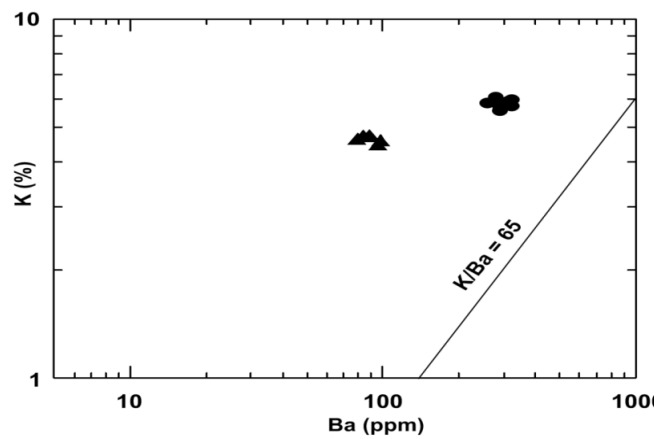

Fig.41: K-Ba variation diagram for the studied alkaline rocks of Gabal Shendib ring complex, average crustal ratio (After Mason, 1966), (Symbols as on Fig. 36)

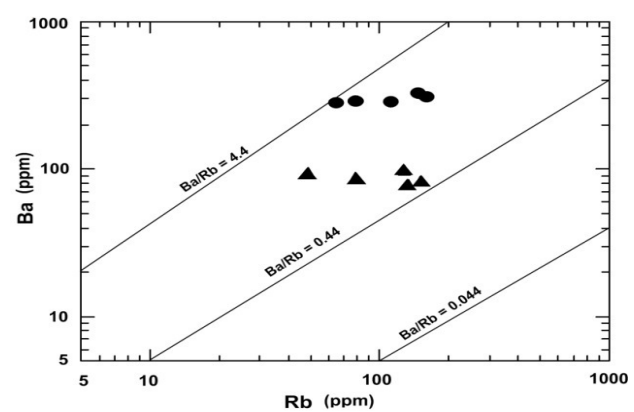

Fig.42: $\mathrm{Rb}-\mathrm{Ba}$ variation diagram for the studied alkaline rocks of Gabal Shendib ring complex(After Mason, 1966), (Symbols as on Fig. 36) relative to $\mathrm{Rb}$ (Fig. 42). According to this diagram the studied alkaline granite and alkaline syenite samples are plotted around the average crustal values ranging between (4.4 and 0.44 ) which indicate high evolution of magma and crystal-melt fractionation. The $\mathrm{Rb}$ versus $\mathrm{Sr}$ diagram (Fig.43), indicate that the studied alkaline rocks consistent dominantly with alkali feldspar fractionation indicating a good agreement with their hypersolvus character and the predominace of perthites and higher proportion of alkali feldspar fractionation required to evolve the peralkaline rocks of Gabal Shendib ring complex.

\section{Rare Earth Element Geochemistry}

The concentration of $\Sigma$ REE in the studied alkaline rocks show a significant variation (range from $215 \mathrm{ppm}$ to $4027 \mathrm{ppm}$ and an average of $1211 \mathrm{ppm}$ ). Two distinct groups are differentiated: I. REE-relatively rich group with total REE $<337 \mathrm{ppm}$ which includes the alkaline syenite samples, II. REE-highly rich group with $\Sigma$ REE up to $4027 \mathrm{ppm}$ which includes the alkaline granite samples (Table 3). The REE-relatively rich group (Group I) displays chondrite-normalized pattern (Fig. 44) with weak to moderate LREE/HREE fractionation (6 to 11) and a moderate negative $\mathrm{Eu}$ anomaly $\left(\mathrm{Eu} / \mathrm{Eu}^{*} \approx 0.2-0.4\right)$. The REE-highly rich group (Group II), on the other hand,

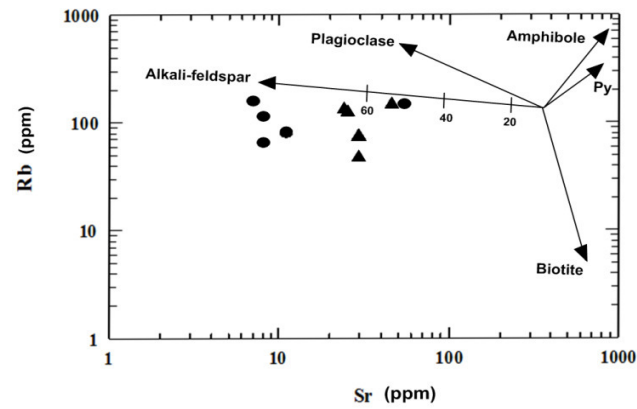

Fig. 43: $\mathrm{Sr}$ versus $\mathrm{Rb}$ variation diagram for the studied alkaline rocks of Gabal Shendib ring complex (After Mason,1966), symbols as on Fig.36 
Table 3: Rare earth element constituents (ppm) of the studied alkaline granite and alkaline syenite

\begin{tabular}{lrrrrrrrr} 
& & & & & & & \\
\hline S.No. & & Alkaline & granite & & & Alkaline syenite \\
& Sh6 & Sh9 & Sh13 & Sh5 & Sh7 & Sh8 & Sh12 \\
\hline La & 33.39 & 19.61 & 553.00 & 63.07 & 37.77 & 34.48 & 36.50 \\
Ce & 82.50 & 46.79 & 1581.35 & 193.39 & 116.63 & 83.06 & 82.89 \\
Pr & 13.18 & 5.92 & 214.94 & 27.48 & 17.12 & 10.49 & 10.28 \\
Nd & 70.22 & 2782 & 1145.33 & 153.35 & 89.78 & 50.38 & 46.82 \\
Sm & 18.34 & 9.80 & 299.74 & 42.32 & 23.92 & 16.23 & 12.67 \\
Eu & 1.24 & 1.11 & 4.63 & 1.87 & 3.06 & 1.53 & 0.85 \\
Gd & 8.63 & 7.70 & 55.65 & 12.46 & 19.70 & 15.20 & 7.30 \\
Tb & 1.48 & 1.32 & 16.47 & 2.33 & 3.29 & 2.15 & 1.25 \\
Dy & 7.69 & 8.00 & 85.94 & 16.40 & 16.66 & 9.29 & 7.06 \\
Ho & 1.96 & 1.74 & 24.15 & 2.65 & 2.65 & 1.82 & 1.99 \\
Er & 3.40 & 3.37 & 36.54 & 5.28 & 4.85 & 3.23 & 4.65 \\
Tm & 0.60 & 0.39 & 2.75 & 0.81 & 0.62 & 0.48 & 0.45 \\
Yb & 2.73 & 2.00 & 3.74 & 3.74 & 1.94 & 2.18 & 2.16 \\
Lu & 1.08 & 0.46 & 2.48 & 0.70 & 0.22 & 0.72 & 0.29 \\
LREE & 219 & 2865 & 3799 & 481 & 288 & 196 & 190 \\
HREE & 28 & 25 & 228 & 44 & 50 & 35 & 25 \\
IREE & 246 & 2890 & 4027 & 526 & 338 & 231 & 215 \\
LREE/HREE & 8 & 115 & 17 & 11 & 6 & 6 & 8 \\
Eu/Eu* & 0.3 & 0.4 & 0.1 & 0.2 & 0.4 & 0.3 & 0.2 \\
Ce/Ce' & 0.922 & 0.219 & 1.072 & 1.090 & 1.106 & 1.015 & 0.999 \\
Pr/Pr' & 1.001 & 0.046 & 0.996 & 1.003 & 1.059 & 0.984 & 0.993 \\
(La/Yb)cn & 8.3 & 6.6 & 99.9 & 11.4 & 13.2 & 10.7 & 11.4 \\
(Tb/Yb)cn & 2.3 & 2.8 & 18.8 & 2.7 & 7.3 & 4.2 & 2.5 \\
(Gd/Yb)cn & 2.6 & 3.1 & 12.0 & 2.7 & 8.2 & 5.6 & 2.7 \\
(La/Sm)cn & 1.1 & 1.3 & 1.2 & 0.9 & 1.0 & 1.3 & 1.8 \\
Tm/Tm' & 0.968 & 0.841 & 0.690 & 1.126 & 1.341 & 0.917 & 0.913 \\
Yb/Yb' & 0.495 & 0.643 & 0.177 & 0.783 & 0.903 & 0.527 & 0.848 \\
t1 & 1.00 & 0.10 & 1.03 & 1.05 & 1.08 & 1.00 & 1.00 \\
t3 & 0.90 & 1.00 & 1.12 & 1.17 & 1.11 & 0.92 & 0.85 \\
t4 & 0.70 & 0.70 & 0.35 & 0.94 & 1.10 & 0.70 & 0.90 \\
TE1,3 & 0.90 & 0.30 & 1.07 & 1.11 & 1.10 & 0.961 & 0.92 \\
TE1,4 & 0.80 & 0.30 & 0.60 & 0.99 & 1.10 & 0.834 & 0.94 \\
\hline & & & & & & & \\
& & & & & & \\
& & & & &
\end{tabular}

shows moderately to highly fractionated chondrite-normalized pattern (Fig.45) with LREE/ HREE ratios range from 8 to 115 and negative Eu anomaly $\left(\mathrm{Eu} / \mathrm{Eu}^{*} \approx 0.1-0.4\right)$ similar to the first group.

\section{REE Tetrad Effect}

The term 'tetrad effect' in geochemistry refers to the subdivision of the 15 lanthanide elements into four groups in a chondrite normalized distribution pattern: (1) $\mathrm{La}-\mathrm{Ce}-\mathrm{Pr}-$ $\mathrm{Nd}$, (2) Pm-Sm-Eu- Gd, (3) Tb-Dy-Ho and (4) $\mathrm{Er}-\mathrm{Tm}-\mathrm{Yb}-\mathrm{Lu}$, and each group forms a smooth convex (M-type) or concave (W-type) pattern (Masuda et al.,1987). The values of tetrad effect were calculated according to the quantification method of Irber (1999):t1 = $\left(\mathrm{Ce} / \mathrm{Ce}^{*} \times \mathrm{Pr} / \mathrm{Pr} *\right), \mathrm{t} 3=\left(\mathrm{Tb} / \mathrm{Tb}^{*} \times \mathrm{Dy} / \mathrm{Dy}{ }^{*}\right), \mathrm{t} 4$ $=\left(\mathrm{Tm} / \mathrm{Tm}^{*} \times \mathrm{Yb} / \mathrm{Yb}^{*}\right)$, Degree of the tetrad effect $\mathrm{T} 1,3=(\mathrm{t} 1 \times \mathrm{t} 3) 0.5$.

In most geological samples the chondrite-normalized REE abundances form a smooth linear or curvilinear trend, which is the famous Masuda-Coryell diagram (Henderson, 1984; Rollison, 1993). Masuda and Ikeuchi (1979) first found the W-type REE tetrad effect in various marine materials, including

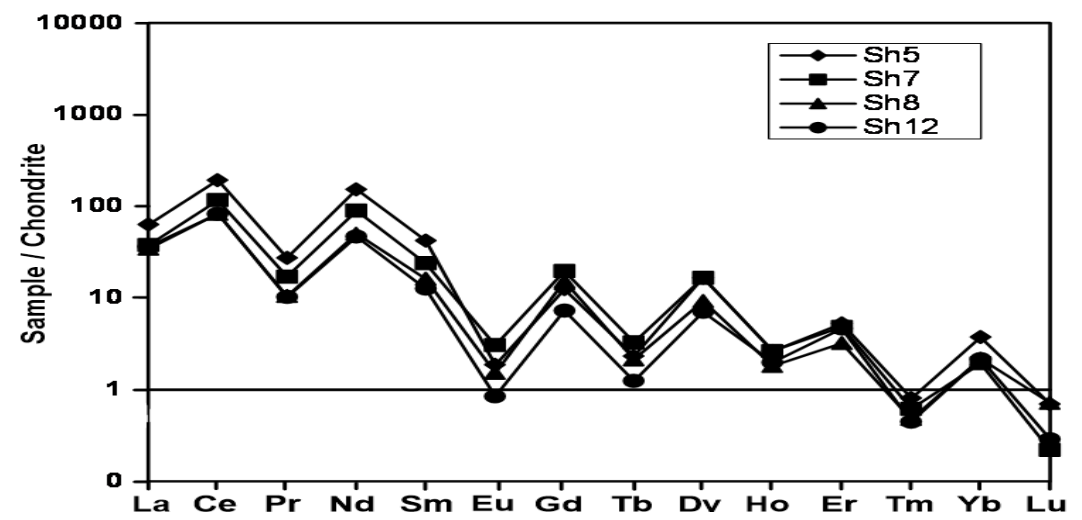

Fig. 44: Chondrite-normalized REE pattern for the alkaline syenite of Gabal Shendib ring complex. The chondrite values for the normalization are from Boynton (1984) 


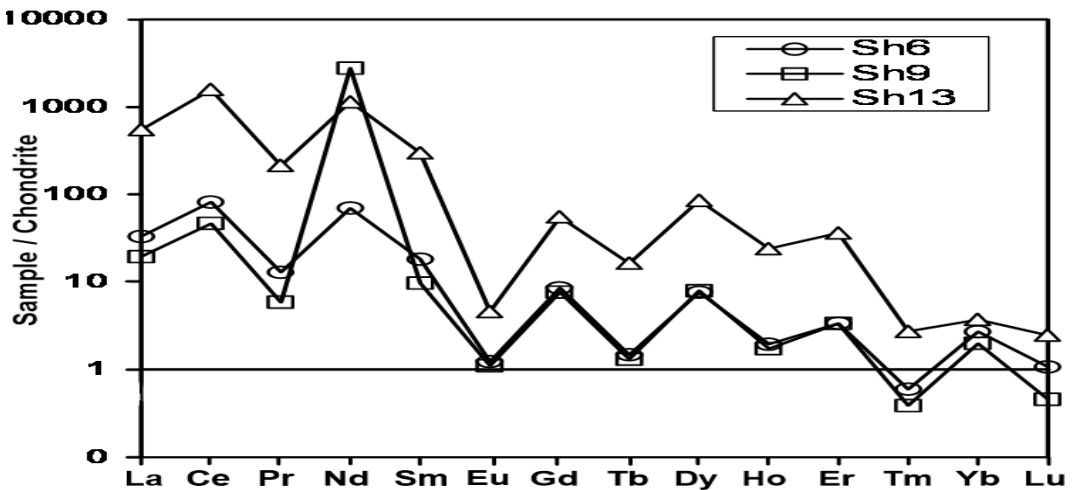

Fig. 45: Chondrite-normalized REE pattern for the alkaline granite of Gabal Shendib ring complex. The chondrite values for the normalization are from Boynton (1984)

sea water, algae, sponges, shells limestones, etc., and soon afterwards, they found similar REE distribution feature in groundwater. Masuda et al. (1987) and Zhao $(1988,1992)$ found the M-type REE tetrad effect in rare-metal granites of South China. Bau (1996) and Irber (1999) also found the same feature in granites of Egypt and Germany. Ratios, such as (La/ $\mathrm{Yb})_{\mathrm{N}},(\mathrm{La} / \mathrm{Sm})_{\mathrm{N}},(\mathrm{Gd} / \mathrm{Yb})_{\mathrm{N}}$ and $\mathrm{Eu} / \mathrm{Eu}{ }^{*}, \mathrm{Ce} /$ $\mathrm{Ce}^{*}$ can provide important petrogenetic and metallogenic information (Schilling, 1975; Jahn et al., 1982; Frey, 1984; Rollison, 1993).

Chondrite-normalized pattern (Fig.44) shows that alkaline syenite sample (Sh5) has strong M-type tetrad effect in the third tetrad effect, while sample (Sh12) show strong W-type tetrad effect in the third tetrad effect (Table 3), suggesting changes in physicochemical conditions that prevailed during hydrothermal alteration of these rocks.

Chondrite-normalized pattern (Fig.45) shows that all samples of alkaline granite and one sample of alkaline syenite (Sh8) have strong W-type tetrad effect in the fourth tetrad effect Table (3). The index of tetrad effect intensity, $\mathrm{TE}_{1,3}$, is higher than 1.10 in one sample of alkaline syenites. On the other hand, the index of tetrad effect intensity, $\mathrm{TE}_{1,4}$, is lesserr than 0.9 in all samples of alkaline granites ranging from 0.3 to 0.8 and one sample (Sh8) in alkaline syenite reach up to 0.83 which implies that there was an interaction between melt and water-haloid-rich fluid when these rocks are crystallized from magma.

\section{CONCLUSIONS}

The alkaline rocks of Gabal Shendib ring complex are composed of olivine gabbro, alkaline granite, alkaline syenite and remnants of the volcanic rocks represented by porphyritic trachyte, porphyritic rhyolite, rhyolite and associated pyroclastics. Distribution of mineralization in the alkaline rocks indicate a post-magmatic hydrothermal fluides. These alkaline rocks provided a source for the mineralizing elements such as $\mathrm{Zr}, \mathrm{Y}, \mathrm{Nb}, \mathrm{Th}$, $\mathrm{U}$ and REE. Geochemical variation of $\mathrm{Rb} / \mathrm{Sr}$ and $\mathrm{Ba} / \mathrm{Rb}$ ratios indicate variable degree of fractionation trend in the Gabal Shendib complex magma. The highest $\mathrm{Rb} / \mathrm{Sr}$ ratio and lower $\mathrm{Ba} / \mathrm{Rb}$ ratio indicate to alteration processes and high degree of fractionation. The behaviors of $\mathrm{Rb}, \mathrm{Ba}$ and $\mathrm{Sr}$ suggest that the development of volatile-rich residual fluids in Gabal Shendib complex magma. Chondritenormalized REE pattern for the alkaline rocks of Gabal Shendib ring complex display 
M-type and W-type tetrad effect and strong Eu depletion in both whole rock samples indicating fluid-melt interaction, enrichment of volatile, alkaline, rare earth elements and rare metals $(\mathrm{Zr}, \mathrm{Y}, \mathrm{Nb}, \mathrm{U})$ in the late stage of fractional crystallization.

\section{REFERENCES}

Abdallah, H.M, 2006. An Overview on the REE mineralized Alkaline Granites in Egypt, with Special Reference to the Abu Khruq and Gara El Hamra Bodies. Resource Geology, 56, no.3, 365-370.

El Agami, N.L.; Abu Baker, M. A.;Ibrahim, M. E., and Rashed, M.A., 1999. Mineralogical and geochemical studies on some mineralization in Halaib area, south Eastern Desert, Egypt. J. Geol., 43/1, 27-34.

Abu Elatta, S.A. ; Assran, H.M., and Ahmed, A. A., 2013. Preliminary Study on HFSE Mineralization in the Peralkaline Granites of Nusab El Balgum Area, South Western Desert, Egypt. Geomaterials, 3, 90 -101.

Bailey, D.K., 1964. Crustal warping.A possible tectonic control of alkaline magmatism. J. geophys. Res'., 69, 1103-1111.

Ball, J., 1912. The geography and geology of south eastern Egypt. Geol. Surv., Cairo, 394p.

Barberi, F.; Bonatti, E.; Marinelli, G., and Varet, J., 1974. Transverse tectonics during the split of a continent: data from the Afar rift. Tectonophysics, 23, 17-29.

Bau, M., 1996. Controls on the fractionation of isovalent trace elements in magmatic and aqueous systems: evidence from $\mathrm{Y} / \mathrm{Ho}, \mathrm{Zr} / \mathrm{Hf}$ and lanthanide tetrad effect. Contrib. Mineral. Petrol., 123, 323-333.

Black, R.; Lameyer, J., and Bonin B., 1985. The Structural Set-ting of Alkaline Complexes, J. Afri. Earth Sciences, 3, No. 1-2, 5-16.

Darwish, M.S., 2003. Geochemical, mineralogical and radioactive studies in Elba area, south
Eastern Desert, Egypt. Ph. D. Thesis, Fac. Sci., Mansoura Univ., Egypt, 261p.

DeGruyter, P.D.; Vogel, T.A., 1981. A model for the origin of the alkaline complexes of Egypt. Nature 291, 571-574

El Alfy, Z.; Bagddady, M.; Awaga, G.; Morsei, A.; Ramadan, T., and Abdallah, M. A., 1994. Geochemical exploration of Elba - Gerf area south Eastern Desert, Egypt, Geol. Surv. , Cairo (unpublished report).

El Ramly, M. F.; Budanov, V. I.; Armanious, L. K., and Dereniuk, N. E., 1969. The three ring complexes of Gabal El Kahfa, GabalNigrub El Fogani and Gabal El Naga, south Eastern Desert of Egypt. Geol. Surv. Egypt, paper No. 52, $39 \mathrm{p}$.

El Ramly, M.F.; Budanov, V.I.; Hussein, A. A., and Dereniuk, N.E., 1970. Ring complexes in the south Eastern Desert of Egypt. In: Studies of some mineral deposits of Egypt, (Osman Moharam et al., Eds.), Geal. Surv. Egypt , 181194.

El Ramly, M.F.; Budanov, V.I., and Hussein, A. A., 1971. The alkaline rocks of south Eastern Desert, Egypt. Geol. Surv. Egypt, Paper no. 53.

El-Ramly, M.F; Hussein A.A.A., 1985. The ring complexes of the Eastern Desert of Egypt. J. Afr. Earth Sci., 3, 77-82.

El Reedy, M.W.M., 1979.Geochronological and geochemical studies on the alkalinec rocks in the South Eastern Desert, Ph. D. Thesis, Fac. Sci., Cairo Univ., 290p.

Egyptian Geological Survey, 1999. The basement rocks of Gabal Elba Quadrangle, Scale, 1:250,000. Geol. Surv. Egypt, Cairo.

Frey, F.A., 1984. Rare earth element abundances in upper mantle rocks. In: Rare Earth Element Geochemistry (Henderson, P., Ed.). Developments in Geochemistry, 2, 153-192.

Harris, N.B.W., 1985. Alkaline complexes from the Arabian Shield. J. Afr. Earth Sci., 3, 83-88.

Hashad, A. H., and El Reedy, M.W.M., 1979. Geo- 
chronology of the anorogenic alkaline rocks, south Eastern Desert, Egypt. Ann. Geol. Surv. Egypt, 9, 81-101.

Henderson, H., 1984. General geochemical properties and abundances of the rare earth elements. In: Rare Earth Element Geochemistry (Henderson, P., Ed.). Develpoments in Geochemistry, $2,1-9$.

Henderson,H., 1996. Rare earth elements, introduction and review. In: Rare earth minerals:Chemistry, origin and deposits (Jones, A.P.; Wall, F. and Williams, C.T., Eds.). The Mineralogical Society Series, 1-19.

Hume, W.F., 1935. Geology of Egypt. II. The fundamental Precambrian rocks of Egypt and Sudan : Part I, The metamorphic rocks : $1-300$, Part II, The later plutonic and minor intrusive rocks : 301-688, Part III, The minerals of economic value : $689-900$. Geol. Surv. Egypt.

Hussein, I. M., 1977.Geology of the Halaib area of the northern Red Sea Hills, Sudan, with reference to the Sol Hamed basic complex. M. Sc. Thesis, Portsmouth Polytechnic, England.

Ibrahim, M. E.,1999. Tectonic evolution and uraium potentiality of Elba ring complex, south Eastern Desert, Egypt. Egyptian Mineralogist, 11, 39-62.

Ibrahim, M.E.; Saleh, G.M.; Darwish, M.S., and Khalaf, M. A., 2006. Mineralogy, spectrometric investigations and geochemistry of manganese ore in Halaib area, south Eastern Desert. $7^{\text {th }}$ Inter. Conf. Geochem., Alexandria, Egypt.

Irber, W., 1999. The lanthanide tetrad effect and its correlation with $\mathrm{K} / \mathrm{Rb}, \mathrm{Eu} / \mathrm{Eu}^{*}, \mathrm{Sr} / \mathrm{Eu}, \mathrm{Y} / \mathrm{Ho}$ and $\mathrm{Zr} / \mathrm{Hf}$ of evolving peraluminous granite suits. Geochim. Cosmochim. Acta, 63, 489-508.

Irvine, T.N., and Baragar, W.R.A., 1971. A guide to the chemical classification of the common volcanic rocks. Canadian J. Earth Sci., 8, 523 $-548$

Jahn, B. M.; Gyuau, G., and Glikson, A., 1982. Komatiites of the overwacht group, S. African: REE geochemistry, Sm/Nd age and mantle evo- lution. Contrib. Mineral. Petrol., 80, 25-40.

Lie'geois, J.P., and Black R., 1987. Alkaline magmatism subsequent to collision in the Pan-African belt of the Adrar des Iforas (Mali). In: Alkaline igneous rocks (Fitton JG., Upton, BJG., Eds). J Geol. SocLond, Special Publication, 30, 381-401

Maniar, P. D., and Piccoli, P. M., 1989. Tectonic discrimination of granitoids. Geol. Soci. Am. Bull., 101, 63 5-643.

Mason, B., 1966. Principles of geochemistry. $3^{\text {rd }}$ Edition., John-Wiley \& Sons, New York, 239 p.

Masuda, A., and Ikeuchi, Y., 1979. Lanthanide tetrad effect observed in marine environment. Geochem. J., 13, 19-22.

Masuda, A.; Kawakami, O.; Dohmoto, Y., and Takenaka, T., 1987. Lanthanide tetrad effects in nature: two mutually opposite types, W and M., Geochem. J., 21, 119-124.

Middlemost, E. A. K., 1975.The Basalt Clan. Earth Science Reviews, 11, 337-364.http://dx.doi. org/10.1016/0012-8252(75)90039-2

Nasr, B.B., and Youssef, M., 1995. New occurrences of Tertiary alkaline rocks at Gebel Elba area South Eastern Desert, Egypt. Ann. Geol. Surv., XX. , $871-873$.

Pearce, J. A.; Harris, N.B., and Tindle, A.G., 1984. Trace element Discrimination diagrams for the tectonic interpretation of granitic rocks. J. Petrology, 25, 956-984.

Rollinson, H., 1993. Using Geochemical Data: Evaluation, Presentation, Interpretation. Longman Scientific Technical, 133-142.

Schilling, J. G., 1975. Rare-earth variations across "normal segments" of the Raykjanes Ridge, $60-53^{\circ} \mathrm{N}$, Mid-Atlantic Ridge, $29^{\circ} \mathrm{S}$, and East Pacific Rise, $2-19^{\circ} \mathrm{S}$, and evidence of the composition of the underlying low-velocity layer. J. Geophys. Res., 80, 1459-1473.

Serencsits, C. M.; Faul, H.; Foland, K. A.; Hussein, A. A., and Lutz, T. M., 1981.Alkaline ring 
complexes in Egypt; their ages and relationship in time. J. geophys. Res, 84, 3009-3013.

Shahin, H. A. A., 2000. Geological, petrographical and geochemical studies of Gabal Elba area south Eastern Desert, Egypt, Ph. D. Thesis, Fac. Sci. Al- Azhar Univ., 220p.

Shahin, H. A. A., 2014. Zr-Y-Nb-REE mineralization associated with microgranite and basic dykes at EL Sela shear zone, south Eastern Desert, Egypt.Springer Plus, 3, 573.

Shaw, D. M., 1968. A review of K/Rb fractionation trends by covariance analysis. Geochim. Cosmo-chim., Acta, 32, 573-601.

Shellnutt, J.G., and Zhou, M.-F., 2007. Permian peralkaline, peraluminous and metaluminous A-type granites in the Panxi district, SW China: their relationship to the Emeishan mantle plume. Chem. Geol., 242, 286-316.

Shellnutt, J.G.; Zhou, M.-F. , and Zellmer, G.F., 2009a. The Permian Baima Igneous Complex (SW China): the role of Fe-Ti oxide crystallization in the formation of A-type granitoids with implication for the Daly gap. Chem. Geol., 259, 204-217.
Takla, M.A.; Basta, E.Z.; El-Sharkawi, M. A., and Fawzie, E.,1976. The mineralogy of some wolframite veins from Egypt. Bull., Fac. Sci., Cairo Univ, No. 49.

Taylor, S. R., 1965. The application of trace element data problems in petrology. In: Physical and chemical of the earth (Ahrens, L.H., Press, F., Runcor, S.R. and Urey, H. C. , Eds), 133213.

Vail J.R., 1985a. Alkaline ring complexes in Sudan. J. Afr. Earth Sci., 3, 51-59.

Vail J.R., 1990. Geochronology of the Sudan. Overseas Geology and Mineral Resources, 66, 58p.

Zhao, Z. H., 1988. REE tetrad effects-an important indicator for fluid/melt interaction. Proc. $3^{\text {rd }}$ Congress on Mineralogy, Petrology and Geochemistry of China, 47-49 (in Chinese with English abstract).

Zhao, Z. H., 1992. Petrogenetic models of crusttype and crust-mantle type granitoids as evidenced by REE patterns. In: Petrogenesis and Mineralization of Granitoids (Tu, Guang-zhi, Xu, Keqin and Qiu,Yuzhuo, Eds.), 54-65, Science Press, Beijing.

\section{جيولوجية وكيميائية واشعاعية معقدة جبل شنديب القلوية، جنوب الصحراء الشرقية، مصر$$
\text { حسن عبد الرازق شاهين و مسعود صلاح مسعود }
$$$$
\text { تكون معقدة جبل شنديب طبوغر افية عالية من الوحدات الصخرية على شكل نتو ء دائرى. }
$$$$
\text { هذه المعقدة بيلغ قطر ها حو الى ب ا كيلومنر قاطعة الصخور البركانية القديمة وضخور التوناليت }
$$$$
\text { ــر انوديورايت. تتكون هذه المعقدة من صخور الجابرو الحديث و صخور الجرانيت القلوى }
$$$$
\text { وصخور السيانيت القلوى وبقايا الصخور البركانية التى يمثلها صخور التر اكيت وصخور }
$$$$
\text { الريوليت. هذه الصخور القلوية تظهر ثراء كبير فى بعض المعادن النادرة منل الزركون الذى }
$$

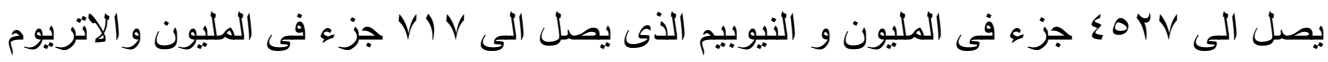

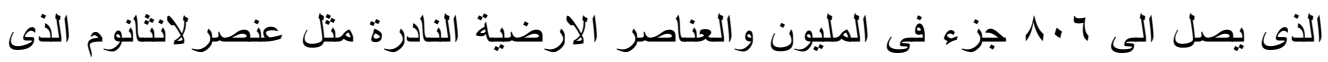

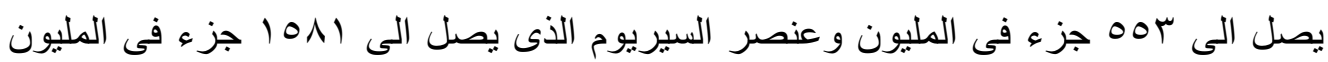


وعنصر البراسوديميوم الذى يصل الى ع اب جزء فى المليون و عنصر النيوديميوم الذى يصل

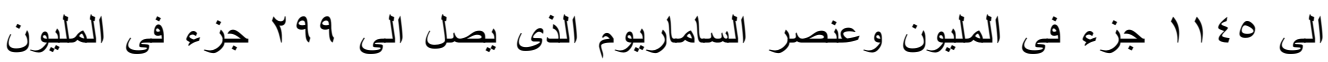

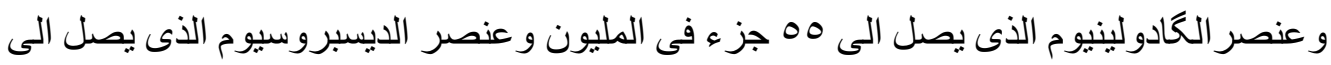

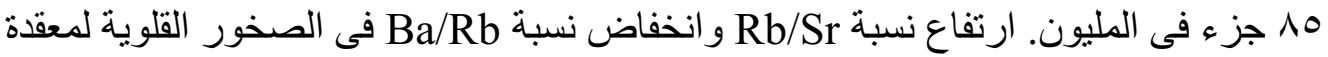

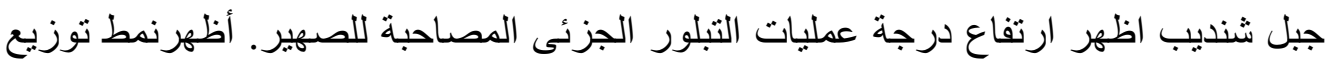

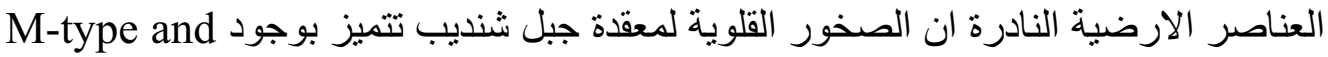
W-type tetrad effect

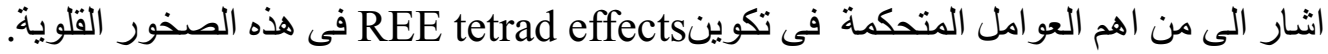
أهم المعادن الحاملة للعناصر الارضية النادرة هى الزير الكيركون و الزونيتيتيم و المونازيت و الالانيت و الاباتيت. كذلك من المعادن الثانوية التى وجدت هى الكولومبيت و اليور انوفين و اليور انوثوريت التئيت

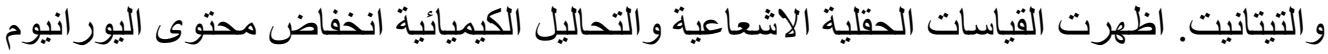
للصخور الجرانيت و السيانيت القلوية لمعقدة جبل شنديب. يصل المستوى الاشعاعى فى صخور

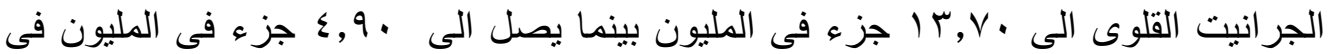

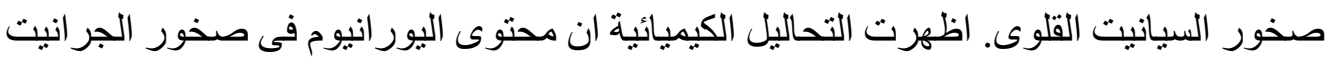
القلوى يصل الى هب جزء فى المليون بينما يصل الى 10 جزء فى المليون فى صخور السيانيت الئي

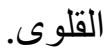

